\title{
Okul Öncesi Öğretmenleri Bakış Açısıyla Millî Değerlerimiz: Türk Büyükleriyle Ahlâk Eğitimi
}

\section{Pre-School Teachers Views on the National Values: Moral Education Through Influential Turkish} Figures

\author{
Abdulhamit KARADEMIR, Sorumlu Yazar, Dr. Öğr. Üyesi. \\ Muş Alparslan Üniversitesi Eğitim Fakültesi, Muş/Türkiye. \\ a.karademir@alparslan.edu.tr \\ https://orcid.org/0000-0003-3062-8547 \\ İlknur ÇELIKK, Öğretmen. \\ T.C. Milli Eğitim Bakanlığı, Ankara/Türkiye. \\ ilknur.6549@gmail.com \\ https://orcid.org/0000-0002-7481-511X
}

ISSN: 1303-880X

e-ISSN: 2667-7504

http://ded.dem.org.tr

Makale Türü / Article Type:

Araştırma Makalesi / Research Article

Geliş Tarihi / Received Date: 03.07.2020

Kabul Tarihi / Accepted Date: 07.10. 2020

Yayın Tarihi / Published Date: 25.12.2020

Tr/En: $\operatorname{Tr}$

Intihal / Plagiarism: Bu makale, en az iki hakem tarafindan incelendi ve intihal içermediği teyit edildi. / This article has been reviewed by at least two referees and scanned via a plagiarism software.
Atıf/Citation: Karademir, A. \& Çelik, İ. (2020). Okul öncesi öğretmenleri bakış aç1sıyla millî değerlerimiz: Türk büyükleriyle ahlak eğitimi. Değerler Eğitimi Dergisi, 18 (40), s.277-306.

https://doi.org/10.34234/ded.762815 
Öz: Araştırmanın amacı, okul öncesi öğretmenlerinin geçmişte yaşamış Türk büyükleriyle ilişkilendirilmiş ahlak eğitimiyle ilgili görüşlerini ortaya koymaktır. Araştırmanın katılımcılarını Muş il merkezinde Millî Eğitim Müdürlüğü'ne bağlı anasınıfları ve anaokullarında görev yapan 23 okul öncesi öğretmeni oluşturmaktadır. Araştırmada veri toplama aracı olarak araştırmacılar tarafindan geliştirilen yarı yapılandırılmış görüşme formu kullanılmıştır. Sonuçlar; öğretmenlerin devlet büyüklerini, tasavvuf büyüklerini, halk kahramanlarını, şair-yazarlar ile bilim alanında öncü birçok ismi Türk büyüğü olarak nitelediğini göstermektedir. Öğretmenlerin bu kişilerle ilişkili ahlak eğitimi denildiğinde; erdemlilik, iman sahibi olma, azim ve başarı, basiretli olma, örnek olma gibi kavramları kullandıkları görülmüştür. Öğretmenlerin birçoğu ahlak eğitimine yönelik özel bir eğitim programı uygulamamaktadır. Ancak büyük çoğunluğunun sınıflarında ahlak eğitimi ile ilgili etkinlikler gerçekleştirmeye çalıştığ1 anlaşılmıştır. Öğretmenlerin ahlaki kavram öğretiminde çoğunlukla drama tekniğini kullanmayı tercih ettiği görülürken, eğitsel oyunların ve görsel-işitsel anlamda desteklenmiş hikâyelerin de kavramlara uygun olarak kullanılmaya çalışıldığı anlaşılmıştır. Öğretmenlerin ahlak eğitimi için, gelişim özelliklerine uygun ve zenginleştirilmiş içeriklerle çocukların olumlu etkileşim kurulabilecekleri etkinliklere yöneldikleri görülmüştür. Katılımcılar, Türk büyüklerinin kişilik özelliklerinin ve ahlaki yapılarının çocuklar tarafından model alınması gerektiğine inanmaktadırlar. Bundan dolayı okul öncesi dönemde Türk büyüklerini içeren ahlak eğitimine sıcak bakmaktadırlar. Tarihimize yönelik materyal yönünden zengin eğitim ortamlarının tasarlanmasının süreçte yararlı olabileceğini belirten öğretmenler, sınıflarda kalıcı Türk Büyükleri merkezinin kurulabileceğini belirtmişlerdir.

Anahtar kelimeler: Okul öncesi dönem, Ahlak eğitimi; Türk büyükleri, Okul öncesi öğretmenleri.

$\&$

Abstract: The aim of this study was to determine preschool teachers' views of moral education through influential Turkish historical figures. The sample consisted of 23 preschool teachers from nursery classrooms and kindergartens affiliated with the Directorate of National Education of Muş/Turkey. Data were collected using a semi-structured interview form developed by researchers. It was found that political leaders, Islamic philosophical figures, folk heroes, poets-writers, and scientists are perceived as influential Turkish figures by the participants. When participants' views about giving moral education through these figures, is asked, participants shared concepts such as; virtue, having faith, 
perseverance, and success, being forethoughtful, and setting an example. Most participants do not implement a program tailored for moral education, but most of them try to perform activities that involve moral education in their lectures. They use the drama as well as educational play and audio-visual story-reading methods to teach moral concepts. They use moral education activities with enriched content that conforms to students' developmental characteristics and allows them to interact. Participants believe that children should look up to influential Turkish figures for their personality traits and moral principles. Therefore, participants support preschool moral education through influential Turkish figures. Participants think that it would be useful to design educational environments with rich material for historical figures and establish permanent centers for influential Turkish figures could be established in classrooms.

Keywords: Preschool period, Moral education, Influential Turkish figures, Preschool teachers.

(The Extended Abstract is at the end of the article)

\section{Giriş}

Değer, bir toplumda arzulanan, kıymetli görülen ve olması istenen kurallar ve ilkeler olarak tanımlanabilir (Cooper, 2014; Sagiv, 2002). Değer kavramı ile ilişkili olan "Ahlak" kavramı ise insanların toplum içinde uymak zorunda oldukları kurallar olarak adlandırılabilir (Akalın, 2009). Değerler ve ahlaki prensipler toplumdan topluma farklılık gösterebilmektedir. Bunu anlamak için toplumların tarih içinde ki yaşam şekline bakmak gerekir. Yerli yabancı birçok düşünür ve yazar eserlerinde; Türk toplumunun iyi niyet, ahde vefa, çalışkanlık, yardımseverlik, cömertlik, birliktelik, hoşgörü, terbiye ve dini kurallara bağlılık noktasında sahip olduğu ahlaki özelliklerden bahseder (akt: Sarı, 2018). Doğruluk, cömertlik, dostluk, sadakat, saygı, sevgi, kanaat, sır saklamak, yalan söylememek ve hirsızlık yapmamak bu toplum bireylerinin genel ahlaki özellikleri arasındadır. Gelenek ve göreneklerine bağlı olduğu bilinen Türk toplumunun, kültürel ve ahlaki değerlerin aktarımına da önem verdiği söylenebilir (Arslanoğlu, 2016). Ahlaki değerlerin kazandırılması ve yeni nesillere aktarılması, toplumun gelişimi ve bireyler için önemli bir yere sahiptir (Aydın, 2003). Bireylerin toplumu oluşturduğu düşünüldüğünde, bireylerin yaşadığı hayat düzenine uyum sağlayarak mutlu olmayı öğrenmeleri toplumsal uyum ve tutarlılık için gereklidir. Toplumsal birliktelik; gelenek-görenekler, sosyal kurallar, kültürel değerler, ahlak ve inanç yardımıyla gerçekleşmektedir (Yavuz, 2012). Değerler ve ahlak, 
her insanın yaşadığı çevre ve deneyimleriyle yakından ilgilidir. Anne- baba ve eğitimciler çocuklarına değer eğitimi ismi altında olmasa da temel değerlere ve temel ahlaki prensiplere yönelik eğitim vermektedirler (Balat ve Dağal, 2006).

Ahlak ve değer anlayışı doğuştan gelen ve bireylere aktarılan bir olgu değildir. Yaşantı ile biçimlenen, eğitim yaşantısıyla sürekli gelişen dinamik bir sürecin ürünüdür (Aydın, 2003). Değerler eğitimi ile varılmak istenen hedef; karakterli, ahlâklı, kişilik sahibi dürüst bireyler yetiştirmektir. Akbaş (2008, s.11-23)'a göre, değer eğitiminde 7 tür yaklaşımdan söz edilebilir. Bunlar; değer gerçekleştirme, değer açıklama, değer analizi, ahlaki muhakeme, karakter eğitimi, vatandaşlık eğitimi, ahlaki eğitim şeklinde sıralanabilir. Ahlak eğitimi yaklaşımında da, ahlaki gelenek, adalet, iyi ve doğrunun anlaşılması, sevilmesi, yüksek seviyeli muhakeme, şefkat ve fedakârlık, diğerlerini düşünmek, özverili olmak, kendini kontrol, alçak gönüllülük ve ahlaki alışkanlık kazanma gibi değer ve uygulamalar programın temeli kabul edilir. (Uygun, 2013).

Her eğitim kademesinde geliştirilmesi gerekli değerler olduğu gibi, erken dönemlerden itibaren tasarlanan etkili programlar ile çocukların zihinsel, duygusal ve ahlaki gelişimleri desteklenebilir. Çocuklar bu sayede eğitimsel hedefler çerçevesinde ahlaki değerleri kazanarak içselleştirebilir (Aydın, 2003). Çocuklar ahlaki değerlere ilişkin bilgileri yaşamları boyunca öğrenmektedirler ama ilk bilgiler erken dönemde kazanılmaya başlanır. Erken çocukluk, ahlaki değerlere ilişkin adımların atıldığ 1 ilk dönemdir. Bu süreç yaşam boyu devam etmektedir. Ancak temel değerler bu dönemde oluşmaktadır (Balat, 2006, s. 7). Erken çocukluk dönemi (EÇD); doğumla başlayan, 6 yaşına kadar devam eden bir süreçtir. Gelişimin son derece hızlı olduğu okul öncesi olarak da adlandırılan bu dönem, aynı zamanda çocuk açısından zihinsel, duygusal ve ahlak gelişimi için kritiktir.

Okul öncesi eğitim (OÖE); “Çocuğun özelliklerine uygun olarak, tüm gelişim alanlarını toplumun kültürel değerleri doğrultusunda yönlendiren, duyguların gelişimini ve algılama gücünü artırarak akıl yürütme sürecinde ona yardımc1 olan ve yaratıcılığını pekiştiren: Onların millî, manevi, ahlaki, kültürel ve insani değerlere bağlıllı̆ını geliştiren kendini ifade etmesine, öz denetimlerini sağlayabilmesine ve bağımsızlığını kazanmasına olanak sağlayan sistemli bir eğitim sürecidir" (http://ooegm.meb.gov.tr/program) biçiminde tanımlanmıştır. Bu dönemde verilmesi gereken kültürel ve ahlaki değerler barındıran; geçmişi örnek gösteren; içine tarihi olay ve şahsiyetleri de alan bir eğitim anlayışı OÖE’nin amaçları ile örtüşmektedir. Okul öncesinde kazandırılması hedeflenen değerlere bakıldığında ise sorumluluk, saygı, sevgi, yardımlaşma, işbirliği, iyilik, hoşgö- 
rü, barış ve özgüven kavramları görülür (Uygun, 2013).

OÖE programında bahsedilen amaç ve değerleri çocuğa kazandırmak için, Türk toplumunu yansıtan, tarihe ve topluma öncü olmuş kahramanlar, ahlaki ve erdemli yaşayışı ile uygun kaynağı oluşturacağı öngörülebilir (Daysal-Ersoy, 2011). Egan (1988)'a göre 7 yaşına kadar çocuklar basit düzeyde tarihi kahramanları ve olayları düşünerek özdeşim sağlayabilir. Bu dönemde çocuk özdeşim kurmak için doğru modellere ihtiyaç duyar. Her model istenilen düzeyde ahlaki ve kültürel gelişime katkı sunmayabilir hatta bu durum ahlaki gelişime olumsuz etki edebilir (Karataş, 2014; Bushman ve Huesmann, 2006). İyi ve kötünün ayırt edilmesinde kahramanların rolleri ve bu kahramanların yaşantıları, ne için mücadele ettikleri, neye önem verdikleri vb. olgular değer öğretiminde kahramanların kullanılmasını elverişli yapmıştır. Bu kahramanlar aynı zamanda hareketleri ile yaşadıkları toplumun ahlaki standart ve değerlerini ortaya koyan kişilerdir (Yazıcı ve Aslan, 2011). Kültüre uygun örnek şahsiyetlerin çocukların ahlak gelişimine katk1 sunup özgeci bireyler yetişmesine zemin hazırlayacağ öngörülebilir. Türk büyükleri hem çocukların kahramana duyduğu ihtiyacı karşılama hem kültürel alt yapılarını oluşturabilme hem de ahlaki değerleri yaşanmış örnekler ile çocukların hayatına geçirebilmeleri adına kolaylık sağlayacağ düşünülmüştür (Daysal-Ersoy, 2011; Ceran, 2015).

Bu araştırmada konu edilen Türk büyükleri, millî kültürün izlerini taşımaları ile çocukların kültüre ait imgeleri yaşatmalarına ve kültürel değerlere sahip çıkma bilincini oluşturmalarına yardımcı olacaktır. Ulu önder Mustafa Kemal Atatürk'ün dediği gibi "Millî benliğini ve millî değerlerini kaybeden toplumların, ahlaki anlamda yozlaştığını, diğer milletler arasında değerini yitirdiğini, ahlaklı bir nesil için millî ahlak ve karakterin kuvvetlendirilmesi gerekir". Dolayısıyla kendi özümüze ve ahlak değerlerimize duyulan tereddütlere karşın öz değerlerimize yeniden bilinçli bir şekilde dönülmesi gerektiğini düşünülmektedir. Ahlaki değerlerimize, kültürel mirasımıza sahip çıkılması ve kalıcılığın sağlanması için ahlak eğitimine erken çocukluk dönemi ile başlanıp, öncü şahsiyetlerimizin yeni nesle örnek gösterilerek, çocukların kültüre uygun ahlaki değerleri geliştirmelerine temel oluşturulabilir (Demircioğlu ve Tokdemir, 2008; Uysal, 2008). OÖE amaçlarına ve kazandırılması hedeflenen değerlere uygunluk gösteren Türk büyükleri; tarihe, ahlaki değerlere, millî bilinç ve kültüre kaynaklık etmesi bak1mından önemlidir. Bu öneme karşın okul öncesi eğitimde, Türk büyüklerinin yer alacağı ahlak eğitimine ilişkin çok sınırlı araştırma olduğu görülmektedir (Daysal-Ersoy, 2011; Ceran, 2015) Bu araştırmada alınan öğretmen görüşleri benzer araştırmalara kaynaklık etmesi; 2013 yılında güncellen okul öncesi müf- 
redatında eksikliği hissedilen ve kültürümüze özgü kahraman boşluğuna dikkat çekmesi durumu ile önem arz eder. Bununla birlikte ele alınan konu ve örneklerin çocuğun sonraki eğitim hayatına kaynaklık etmesi, bu dönemde atılacak ahlaki, tarihi ve kültürel temellerin gelecek eğitim hayatını da kolaylaştıracağ öngörülebilir. Daha birç̧ok özelliği ile ön planda olan ecdadımıza yakışır bir neslin gelmesi ve bu anlamda ahlaki ve kültürel değerlerimizin kaybolmaması adına yeni kuşaklara bu özgün faziletlerin aktarılması elzemdir.

\section{Yöntem}

\section{Araştırma Modeli}

$\mathrm{Bu}$ araştırmada, nitel araştırma yöntemlerinden fenomenoloji deseni kullanılmıştır. Genel olarak fenomenoloji, bireylerin kendi bakış açılarını, algı ve deneyimlerini ön plana çıkarmayı amaçlayan bir araştırma desenidir (Yıldırım ve Şimşek, 2012). İnsanların yaşama ilişkin tüm algısı, olguların duyuşsal olarak deneyimlenmesi ve bu deneyimlerin kişisel olarak yorumlanmasından kaynaklanmaktadır. Çevreyi anlamlandırmak için deneyimlediğimiz olguları nasıl bir araya getirdiğimiz fenomenolojik araştırmalarının odağını oluşturmaktadır (Patton, 2014).

\section{Katılımcilar}

Kartopu örnekleme yönteminin tercih edildiği araştırmaya katılım gönüllülük esasına dayandırılmıştır. Bu bağlamda Muş İl'inin çeşitli ilçelerinde yer alan anaokullarında ( $\mathrm{n}=21)$ ve ilkokullar bünyesindeki anasınıflarında $(\mathrm{n}=2)$ görevli okul öncesi öğretmenleri ( $\mathrm{n}=23$ ) araştırmaya katılım sağlamıştır. Öğretmenlerin 22'si kadın, 1'i erkektir. Yaş ortalaması $(\mathrm{M}=34)$ olarak hesaplanan öğretmenlerin tamamı okul öncesi eğitimi lisans mezunudur. 7 öğretmenin görevinde 1018 yıl çalıştığı, 12 öğretmenin 5-9 yıl çalıştığı bilgisi edinilmiştir.1-4 yıl görev yapmış 4 ögretmen ise henüz yeni atanmıştır.

\section{Veri Toplama Araçları}

Araştırmada, geçmişte yaşamış Türk Büyükleriyle ilişkilendirilmiş değerler eğitiminin okul öncesi eğitim-öğretim sürecine yansımalarını farklı bakış açılarına dayalı olarak ortaya koymak amaçlanmıştır. Bu amacı gerçekleştirmek için, okul öncesi öğretmenlerine yönelik yarı yapılandırılmış görüşme formlarının 
oluşturulması düşünülmüştür. Görüşme formlarının geliştirilmesi sürecinde ilk olarak kapsam ve içerik belirlenerek araştırmacılar tarafından madde havuzu oluşturulmaya çalışılmıştır. Sonrasında birisi okul öncesi diğeri sınıf eğitimi alanında uzman iki kişiden uzman görüşü alınarak, sorular incelenmiş ve görüşme formlarına son biçimleri verilmiştir. İki aşamadan oluşan yarı yapılandırılmış görüşme formlarında, katılımcıların demografik özelliklerini belirmeye yönelik 4 soru, Türk Büyüklerinin ahlak eğitimi üzerine etkilerini belirlenmeye çalışıldığ 7 soru bulunmaktadır. Öğretmenlerle belirlenen yer ve zamanda yüz yüze görüşmeler yapılarak 2019-2020 eğitim öğretim yılı güz döneminde veriler toplanmıştır.

\section{Veri Analizi Süreci}

Verilerin analizinde ilgili alanyazına ve katılımcıların görüşlerine dayalı olarak tümevarımsal biçimde yapılan içerik analiziyle kodlardan kategoriler, alt temalar ve temalar oluşturularak bulgular tanımlanmış ve bu bulgular içerik analizine göre yorumlanarak ifade edilmeye çalışılmıştır (Krippendorff, 2013). Veriler nitel araştırmalarda kullanılan çift döngüsel kodlama tekniğiyle analiz edilmiş̧ir (Miles, Huberman \& Saldana, 2014). İlk döngüsel düzeyde araştırmacılar birbirlerinden bağımsız olarak verilerin bir kısmını kodlamış ardından bu kodlar karşılaştırılmıştır. Birbirinden bağımsız biçimde oluşan tema ve kategorilerin doğrulanması ve öznel yargılardan uzaklaştırılması için araştırmacılarla birlikte kodlar üzerine tartışarak yeni tema ve kategoriler oluşturulmuştur. İkinci döngüsel düzeyde aynı araştırmacılar verilerden kalan kısımları sabit karşılaştırma tekniği ile kodlamaya devam etmiş̧ir (Corbin \& Strauss, 2008). Görüşmelerde bazen bir kodun birden fazla tema altında yer aldığı görülmüştür. Ardından QSR-NVivo 8 programı araciyla yapılan kodlamalar ve bulgular yorumlanarak ifade edilmeye çalışılmıştır. Güvenirliğinin tekrar sağlanması amacıyla ise tüm veri kodlamaları yapıldıktan sonra, alan hakkında deneyimli farklı bir uzman tarafından kod ve temalar gözden geçirilerek fikir birliği sağlanan verilerin son biçimleri tablolar halinde sunulmuştur.

\section{Bulgular}

Araştırmada, her bir araştırma sorusu altında yer alan temalar, alt temalar, kategoriler, kodlar ve örnek görüşler tablolar halinde sunulurken, görüşme detaylar1na yorumlar kısmında yer verilmiştir. Bu sayede ham verilerden yararlanılarak tabloların yorumlanmasında okuyuculara kolaylık sağlanması amaçlanmıştır. Araştırmaya katılan öğretmenlerin ahlak eğitiminde kullandıkları kavramlara 


\section{yönelik görüşlerinden elde edilen veriler Tablo 1'de sunulmuştur.}

\begin{tabular}{|c|c|c|c|}
\hline Tema & $\begin{array}{l}\text { Alt } \\
\text { Tema }\end{array}$ & Kod & Örnek Görüşler \\
\hline \multirow{31}{*}{$\begin{array}{l}\text { Ahlak } \\
\text { Eğitimi }\end{array}$} & \multirow{10}{*}{ Erdem } & Hoşgörü(N=9) & $\begin{array}{l}\text { Sevgi, hoşgörü, yardımlaşma kavramlarına uygun etkinlik- } \\
\text { ler hazırlanmalı. (Ö20) }\end{array}$ \\
\hline & & Sevgi $(N=9)$ & \multirow{2}{*}{$\begin{array}{l}\text { Paylaşmak, yardımseverlik, hoşgörü kavramlarına yer } \\
\text { verilmeli. (Ö19) }\end{array}$} \\
\hline & & Yardımlaşmak $(\mathrm{N}=6)$ & \\
\hline & & Paylaşmak(N=4) & Sevgi, sayg1, edep ve paylaşmak, kavramları. (Ö9) \\
\hline & & Merhamet $(\mathrm{N}=3)$ & Merhamet, sevgi, hoşgörü, yardımseverlik. (Ö11) \\
\hline & & $\begin{array}{l}\text { Doğruluk ve dürüst- } \\
\text { lük }(\mathrm{N}=6)\end{array}$ & $\begin{array}{l}\text { İyilik yapmak, kibar olmak, doğru sözlü olmak, çalışkan } \\
\text { olmak. (Ö15) }\end{array}$ \\
\hline & & Adalet $(\mathrm{N}=2)$ & \multirow{2}{*}{$\begin{array}{l}\text { Doğruluk, dürüstlük, adalet ve iyi bir birey olma kavrama- } \\
\text { ları. (Ö16) }\end{array}$} \\
\hline & & $\begin{array}{l}\text { Toplum bilin- } \\
\operatorname{ci}(\mathrm{N}=1)\end{array}$ & \\
\hline & & Empati $(\mathrm{N}=1)$ & Sayg1, edep, görgü kuralları, empati, toplum bilinci. (Ö2) \\
\hline & & Çalışkanlık(N=1) & ... çalışkan olmak. (Ö15) \\
\hline & \multirow{10}{*}{$\begin{array}{l}\text { Ahlaki } \\
\text { davranış }\end{array}$} & $\operatorname{Sayg}_{1}(\mathrm{~N}=16)$ & $\begin{array}{l}\text { Değerlerimiz, sorumluluk, nezaket sözcükleri, sevgi, sayg1, } \\
\text { hoşgörü, yardımseverlik. (Ö3) }\end{array}$ \\
\hline & & $\begin{array}{l}\text { Nezaket sözcükle- } \\
\text { ri }(\mathrm{N}=5)\end{array}$ & $\begin{array}{l}\text { Okul öncesinde ahlak eğitimine çok önem veriyorum. } \\
\text { Özellikle nezaket kurallarını, nezaketli konuşmalarını }\end{array}$ \\
\hline & & $\begin{array}{l}\text { Yalan söyleme- } \\
\operatorname{mek}(\mathrm{N}=2)\end{array}$ & $\begin{array}{l}\text { önemsiyorum. Çocukların büyüklerine karşı saygı1ı olmala- } \\
\text { r1 konularını işliyorum. (Ö8) }\end{array}$ \\
\hline & & $\begin{array}{l}\text { Hirsizlık yapma- } \\
\operatorname{mak}(\mathrm{N}=2)\end{array}$ & \multirow{2}{*}{$\begin{array}{l}\text { Yalan söylememek, hırsızlık yapmamak, saygı, hoşgörü, } \\
\text { sevgi kavramları aklıma gelen kavramlar. (Ö5) }\end{array}$} \\
\hline & & Kibarlık(N=2) & \\
\hline & & Edep $(\mathrm{N}=2)$ & ... edep ...Ö2) \\
\hline & & İş birliği(N=1) & İşbirliği, saygı ve sevgi kavramları(Ö10) \\
\hline & & $\begin{array}{l}\text { Güzel davranış- } \\
\operatorname{lar}(\mathrm{N}=2)\end{array}$ & $\begin{array}{l}\text { Davranış, kurallar, saygı, anlayış, kötü söz olmaması, zarar } \\
\text { vermeme, iyi ve kötü davranışın ayrımı, empati kurma } \\
\text { kavramları. (Ö24) }\end{array}$ \\
\hline & & $\begin{array}{l}\text { Benmerkezci dü- } \\
\text { şünmeme( } \mathrm{N}=1)\end{array}$ & $\begin{array}{l}\text { Yardımlaşma, sevgi dolu tavırlar, nazik tavırlar, şefkat, } \\
\text { merhamet, özür dilemek aklıma gelen kavramlar bunlar. } \\
\text { (Ö23) }\end{array}$ \\
\hline & & Üslup(N=1) & $\begin{array}{l}\text { Sayg1, terbiye, örf-adet, değerlerimiz, kültürel ve ailevi de- } \\
\text { ğerler, nezaket sözcükleri ve üslup gibi kavramalar. (Ö22) }\end{array}$ \\
\hline & \multirow{7}{*}{$\begin{array}{l}\text { Ahlaki } \\
\text { kurallar }\end{array}$} & $\begin{array}{l}\text { Nezaket kurallar } \\
(\mathrm{N}=3)\end{array}$ & $\begin{array}{l}\text { Mahremiyet, din eğitimi ve sosyal gelişim sağlanmalı. } \\
\text { (Ö13) }\end{array}$ \\
\hline & & Değerlerimiz $(\mathrm{N}=2)$ & Değerlerimiz ... (Ö3) \\
\hline & & Kurallar(N=2) & \multirow{2}{*}{$\begin{array}{l}\text { Sayg1, terbiye, örf-adet, değerlerimiz, kültürel ve ailevi de- } \\
\text { ğerler, nezaket sözcükleri ve üslup gibi kavramalar. (Ö22) }\end{array}$} \\
\hline & & Mahremiyet(N=1) & \\
\hline & & $\operatorname{Din}(N=1)$ & \multirow{2}{*}{$\begin{array}{l}\text { Büyüğe ve insanlara sayg1, toplumsallar kurallara uyma, } \\
\text { arkadaş hakkına sayg1, paylaşma, nezaket kuralları, izin } \\
\text { isteme gibi kavramlar. (Ö21) }\end{array}$} \\
\hline & & Terbiye $(\mathrm{N}=1)$ & \\
\hline & & Örf-adet(N=1) & $\begin{array}{l}\text { Doğruluk, dürüstlük, farklılıklara ve diğerlerine sayg1, } \\
\text { ortamda bulunurken özgürlük kapsamının öğretilmesi. (Ö1) }\end{array}$ \\
\hline & \multirow{4}{*}{ Diğer } & İyi ve kötü(N=3) & $\begin{array}{l}\text { İyiyi ve doğruyu bilme, güzel davranışlarda bulunma. } \\
\text { (Ö12) }\end{array}$ \\
\hline & & Sorumluluk $(\mathrm{N}=1)$ & ... sorumluluk ... (Ö3) \\
\hline & & Özgürlük(N=1) & \multirow{2}{*}{$\begin{array}{l}\text { OÖD Ahlak eğitimi denilince aklıma ilk gelen vicdan mu- } \\
\text { hasebesi yapabilen çocukların yetiştirilmesi geliyor. İyi ve } \\
\text { kötüyü ayırabilmesi için çocuğa verilen eğitim geliyor. (Ö6) }\end{array}$} \\
\hline & & Vicdan(N=1) & \\
\hline
\end{tabular}

Tablo 1 incelendiğinde okul öncesi öğretmenleri ahlak eğitimi kavramları 
olarak en çok "Erdemli olma, ahlaki davranış ve ahlaki kurallar" cevaplarını vermiş ayrıca öğretmenlerden iyi ve kötü kavramının ayırt edilmesi buna uygun davranışlara karar verirken özgür olunması ve yapılan davranışların sorumluluğunun alınması ile ilgili cevaplar alınmıştır. Türk Büyüklerinin ahlak eğitimi üzerindeki etkilerinin önemli bulunduğu bu araştırmada, öğretmenlerin Türk Büyükleri ve onların özelliklerine ilişkin görüşlerinden elde edilen veriler Tablo 2 'te sunulmuştur.

\begin{tabular}{|c|c|c|c|}
\hline Tema & Alt Tema & Kod & Örnek Görüşler \\
\hline \multirow{22}{*}{$\begin{array}{l}\text { Türk } \\
\text { büyük- } \\
\text { leri }\end{array}$} & \multirow{8}{*}{$\begin{array}{l}\text { Devlet büyük- } \\
\text { leri }\end{array}$} & Atatürk* $(\mathrm{N}=12)$ & \multirow{3}{*}{$\begin{array}{l}\text { Atatürk, Mevlana, Yunus Emre, M.A. Ersoy, Cahit Arf, } \\
\text { Ali Kuşçu, Evliya Çelebi, F.S. Mehmet, K. Sultan Sü- } \\
\text { leyman, Yıldırım Beyazid, İbni Sina, Harezmî, Ömer } \\
\text { Hayyam, Neşet Ertaş aklıma gelen Türk büyükleri. } \\
\text { (Ö12) }\end{array}$} \\
\hline & & $\begin{array}{l}\text { Fatih Sultan Meh- } \\
\text { met*(N=12) }\end{array}$ & \\
\hline & & Kanuni S.S (N=5) & \\
\hline & & Ertuğrul $(\mathrm{N}=2)$ & \multirow{2}{*}{$\begin{array}{l}\text { Farabi, Yunus Emre, Alparslan, Atatürk, K. Sultan } \\
\text { - Süleyman, F.S. Mehmet. (Ö13) }\end{array}$} \\
\hline & & Alparslan*(N=2) & \\
\hline & & Yavuz S.S* $(\mathrm{N}=1)$ & \multirow{3}{*}{$\begin{array}{l}\text { Daha önce plan ve uygulamalarımda Alparslan, Ata- } \\
\text { türk, Fatih Sultan, Mevlana ve Mehmet Akif Ersoy’a } \\
\text { yer verdim. (Ö24) }\end{array}$} \\
\hline & & 2.Abdülhamit $(\mathrm{N}=1)$ & \\
\hline & & Osman Gazi(N=1) & \\
\hline & \multirow{5}{*}{$\begin{array}{l}\text { Tasavvuf } \\
\text { Büyükleri }\end{array}$} & Mevlana* $(\mathrm{N}=20)$ & \multirow{2}{*}{$\begin{array}{l}\text { - Mevlana, Yunus Emre, Seyit Onbaşı, Hezarfen, Nasret- } \\
\text { tin Hoca Hacı Bektaş Veli isimlerini hatırlıyorum. (Ö3) }\end{array}$} \\
\hline & & $\begin{array}{l}\text { Yunus Em- } \\
\text { re*}(\mathrm{N}=11)\end{array}$ & \\
\hline & & Gazali $(\mathrm{N}=3)$ & $\begin{array}{l}\text { Daha önce uygulamalarımda Mevlana, Atatürk ve } \\
\text { Yunus Emre'yi işledim. (Ö11) }\end{array}$ \\
\hline & & 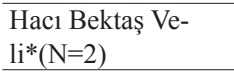 & $\begin{array}{l}\text { Mevlana’ya yer verdim. Belirli gün ve haftalar planı } \\
\text { olarak. (Ö14) }\end{array}$ \\
\hline & & $\begin{array}{l}\text { Ahmet Yese- } \\
\operatorname{vi}(\mathrm{N}=1)\end{array}$ & $\begin{array}{l}\text { Planlarımda Mevlana, Fatih Sultan, Atatürk ve Hacı } \\
\text { Bektaş Veli İsimlerine yer verdim. (Ö3) }\end{array}$ \\
\hline & \multirow{3}{*}{$\begin{array}{l}\text { Halk Kahra- } \\
\text { manları }\end{array}$} & $\begin{array}{l}\text { Nasrettin Ho- } \\
\mathrm{ca}^{*}(\mathrm{~N}=6)\end{array}$ & $\begin{array}{l}\text { M.Akif, Seyit Onbaşı, Nasrettin Hoca' ya planlarımda } \\
\text { yer verdim. (Ö21) }\end{array}$ \\
\hline & & $\begin{array}{l}\text { Seyit Onba- } \\
S_{1}{ }^{*}(\mathrm{~N}=2)\end{array}$ & $\begin{array}{l}\text { Nasrettin Hoca, Keloğlan, Mevlana, Mehmet Akif } \\
\text { Ersoy planımda yer verdiğim isimler. (Ö23) }\end{array}$ \\
\hline & & Keloğlan*(N=1) & $\begin{array}{l}\text { Uygulamada Mevlana, Atatürk ve Nasrettin Hoca } \\
\text { işledim. (Ö18) }\end{array}$ \\
\hline & \multirow{6}{*}{$\begin{array}{l}\text { Şair ve Ya- } \\
\text { zarlar }\end{array}$} & $\begin{array}{l}\text { M. Akif Er- } \\
\text { soy* }(\mathrm{N}=9)\end{array}$ & $\begin{array}{l}\text { İmam Gazali, Mimar Sinan, M.A. Ersoy, Atatürk, F.S. } \\
\text { Mehmet aklıma gelenler. (Ö10) }\end{array}$ \\
\hline & & $\begin{array}{l}\text { Evliya Çelebi } \\
(\mathrm{N}=2)\end{array}$ & \multirow{2}{*}{$\begin{array}{l}\text { Mevlana, Yunus Emre, Barış Manço, Evliya Çelebi, } \\
\text { Farabi, Nasrettin Hoca aklıma gelen Türk büyükleri- } \\
\text { miz. (Ö20) }\end{array}$} \\
\hline & & Âşık Veysel*(N=1) & \\
\hline & & $\begin{array}{l}\text { Ömer Hayyam } \\
(\mathrm{N}=1)\end{array}$ & \multirow{2}{*}{$\begin{array}{l}\text { Mevlana, Âşık Veysel ve Atatürk'e daha önceden } \\
\text { uygulamalarımda yer verdim. (Ö1) }\end{array}$} \\
\hline & & Neşet Ertaş*(N=1) & \\
\hline & & $\begin{array}{l}\text { Barış } \\
\operatorname{Manço*}(\mathrm{N}=1)\end{array}$ & $\begin{array}{l}\text { Evet. Fatih Sultan Mehmet, Mustafa Kemal, Mevlana } \\
\text { planlarımda işlediğim isimler. (Ö13) }\end{array}$ \\
\hline
\end{tabular}




\begin{tabular}{|c|c|c|}
\hline \multirow{9}{*}{$\begin{array}{l}\text { Bilim ve Tek- } \\
\text { nik Öncüleri }\end{array}$} & $\begin{array}{l}\text { Mimar Si- } \\
\operatorname{nan} *(\mathrm{~N}=5)\end{array}$ & Mimar Sinan ve Abdülhamit'i işledim. (Ö7) \\
\hline & Farabi $(\mathrm{N}=5)$ & ... Farabi aklıma gelen Türk büyükleri. (Ö6) \\
\hline & İbni Sina*(N=4) & \multirow{2}{*}{$\begin{array}{l}\text { Atatürk, İbni Sina, Fatih, Mehmet Akif Ersoy, Mevla- } \\
\text { na, Ali Kuşçu, Yunus Emre ve Neşet Ertaş'1 işledim. } \\
\text { (Ö12) }\end{array}$} \\
\hline & Ali Kuşçu (N=4) & \\
\hline & Hezarfen*(N=3) & \multirow{2}{*}{$\begin{array}{l}\text { İbni Sina, Farabi, İmam Gazali, Yunus Emre, Mev- } \\
\text { lana, F.S. Mehmet, K. Sultan Süleyman, 2.Mahmut, } \\
\text { Atatürk, Nasrettin Hoca, Hezarfen, Akşemsettin, Ali } \\
\text { Kuşçu aklıma geliyor. (Ö18) }\end{array}$} \\
\hline & Cahit $\operatorname{Arf}(\mathrm{N}=1)$ & \\
\hline & Akşemsettin (N=1) & ...Akşemsettin ... (Ö18) \\
\hline & Harezmî $(\mathrm{N}=1)$ & ... Harezmi ... (Ö12) \\
\hline & Piri Reis $(\mathrm{N}=1)$ & $\begin{array}{l}\text { Piri Reis, M.Akif, Hezarfen ve Atatürk isimlerine yer } \\
\text { verdim. (Ö22) }\end{array}$ \\
\hline
\end{tabular}

*Uygulamalarda yer verilen Türk Büyüklerine ait özellikler.

Tablo 2 incelendiğinde bilinen Türk büyükleri arasında: Devlet büyüklerinden en çok M.K. Atatürk, F. Sultan Mehmet, Kanuni Sultan Süleyman cevapları verilmiştir. Bu cevapları; Ertuğrul Gazi, Alparslan, Yavuz sultan Selim, 2. Abdülhamit, Osman Gazi, Yıldırım Beyazid cevapları takip etmiştir. Mutasavvıflardan en çok Mevlana ve Yunus Emre alınan cevaplar arasındayken bu cevapları; Hacı Bektaş Veli, İmamı Gazali, Ahmet Yesevi cevapları takip etmiştir. Şair ve yazarlarımızdan M. Akif Ersoy en çok alınan cevap iken bu cevabı; Evliya Çelebi, Âşık Veysel, Ömer Hayyam, Neşet Ertaş, Barış Manço cevapları takip etmiştir. Bilim ve teknik öncüleri: Mimar Sinan, Farabi, İbni sina, Ali kuşçu, Hezarfen Ahmet Çelebi en çok alınan cevaplardır. Bu cevapları Cahit Arif, Harezmî, Ak Şemsettin, Piri Reis cevapları izlemiştir. Halk kahramanlarından en çok Nasrettin Hoca cevabı alınmışken Seyit Onbaşı ve Keloğlan bu cevabı takip etmiştir. Etkinliklerde Türk büyüklerine yer verilme durumunda ise; Devlet büyüklerinden en fazla Atatürk $(\mathrm{N}=12)$ ve Fatih Sultan Mehmet'in( $\mathrm{N}=4)$ etkinliklerde yer aldığg görülmüştür. Bu cevapları; Alparslan( $\mathrm{N}=1)$ ve Yavuz $\mathrm{S} . \mathrm{S}(\mathrm{N}=1)$ cevapları takip etmiştir. Devlet büyükleri denince akla gelen isimler ile planlarda yer verilen Devlet büyükleri arasında anlamlı bir farklılık vardır. Akla en çok gelen isim Fatih sultan Mehmet iken planlarda en çok yer verilen isimin Atatürk olduğu görülmüştür. Bu durumun O.Ö.E programında Atatürk'ün bir kavram olarak açıkça yer almasıyla ilgili olduğu düşünülmektedir. Aynı durumun diğer Türk büyükleri içinde olması O.Ö.E plan ve uygulamalarında işlenme sıklığını arttıracağı söylenebilir. Bunun dişında 13 devlet büyüğü akla gelen cevaplar arasındayken; uygulamalarda sadece bunların 4'üne yer verildiği görülmektedir. Mutasavvıflardan ise en fazla Mevlana( $\mathrm{N}=20)$ uygulamalarda yer almıştır. Yunus Emre( $\mathrm{N}=2)$ ve Hacı Bektaş Veli(N=1) uygulamalarda yer alan diğer mu- 
tasavviflardır. Mutasavvıflardan akla en çok gelen Mevlana iken yapılan uygulamalarda da aynı durum görülmüştür. Yunus Emre'nin akla gelme sıklığ 1 ile uygulanma sıklığı arasında negatif bir ilişki vardır. Bu durumun Mevlana haftası olarak belirli gün ve haftalarda O.Ö.E planlarında yer almasıyla ilgili olduğu düşünülmektedir. Aynı şekilde diğer Türk büyülerini içine alacak bir belirli gün ve haftalar program1; Türk büyüklerinin uygulamalarda yer verilme durumunu arttıracağı öngörülebilir. Aynı zamanda akla gelen mutasavvıf sayısı ile uygulamalarda yer alan isimlerin yarı yarıya düştüğü görülmüsstür. Halk kahramanlarında en çok uygulanan Nasrettin $\mathrm{Hoca}(\mathrm{N}=5)$, ardından Seyit Onbaşı $(\mathrm{N}=3)$ ve Keloğlan'dır(N=1). Bu durum için anlamlı bir farklılık görülmemiştir. Şair ve yazarlardan en çok Mehmet Akif ( $\mathrm{N}=11)$, sırasıyla Barış Manço (N=2) ve Neşet Ertaş $(\mathrm{N}=1)$ uygulanan planlarda yer almıştır. Akla en çok gelen ve uygulamalarda en çok yer alan ismin Mehmet Akif Ersoy olması yine belirli gün ve haftalarda (İstiklâl Marşı'nın kabulü) bulunması ile açıklanabilir. Tablo 2 incelendiğinde akla gelen şair ve yazar sayısı 6 iken uygulamalarda 4 isme yer verilmiştir. Bilim ve teknik öncülerinden Mimar Sinan ( $N=3)$ uygulamalarda en çok yer alan isim olmuştur. İbni sina( $\mathrm{N}=1)$, Aziz Sancar( $\mathrm{N}=1)$, Hezarfen $(\mathrm{N}=1)$ uygulamalarda yer alan diğer isimlerdir. Ayrıca aklınıza gelen Türk büyükleri kimlerdir sorusuna belirtilen isimler daha fazla iken plan ve uygulamalarda aynı isimlere yer verme durumunda bir düşüş görülmektedir. Karşılaştırma yapıldığında en çok uygulanan ve ilk akla gelen isimlerin aynı olduğu görülmektedir. Ayrıca verilen cevaplar da ise bazı bilinen Türk büyüklerine uygulamalar da hiç yer verilmediği görülmüştür.

\begin{tabular}{|c|c|c|c|}
\hline Tema & Alt Tema & Kod & Örnek Görüşler \\
\hline \multirow{7}{*}{$\begin{array}{l}\text { Türk } \\
\text { Büyüklerinin } \\
\text { Özellikleri }\end{array}$} & \multirow{7}{*}{ Erdem } & Sevgi* $(\mathrm{N}=9)$ & \multirow{2}{*}{$\begin{array}{l}\text { Koşulsuz sevgi ve kabul, imanlı olma, } \\
\text { cesaretli olma, vatana ve millete bağlılık } \\
\text { özellikleri vardır. (Ö1) }\end{array}$} \\
\hline & & Cesaret* $(\mathrm{N}=8)$ & \\
\hline & & Çalışkanlık*(N=7) & $\begin{array}{l}\text { Yardımsever, dürüst, çalışkan, zeki, cesaretli, } \\
\text { hoşgörülü ve merhamet sahibi kişilerdi. } \\
\text { (Ö10) }\end{array}$ \\
\hline & & 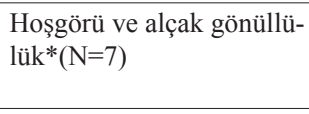 & $\begin{array}{l}\text { Çalışkan ve azimliydiler. Vatan ve Millet } \\
\text { sevgisi, empati ve hoşgörü özelliklerine } \\
\text { sahiplerdi. (Ö2) }\end{array}$ \\
\hline & & $\begin{array}{l}\text { Doğruluk ve dürüst- } \\
\text { lük }(\mathrm{N}=4)\end{array}$ & $\begin{array}{l}\text { Azimli olma, doğruluktan yana olma ve } \\
\text { kahraman olma özellikleri, vatanperverlik ve } \\
\text { inanç anlamında teslimiyet özellikleri vardı. } \\
\text { (Ö5) }\end{array}$ \\
\hline & & Yardımseverlik(N=3) & \multirow{2}{*}{$\begin{array}{l}\text { Mevlana hoşgörülüydü, yardımseverdi. } \\
\text { Araştırmacı, zeki ve liderlerdi. (Ö3) }\end{array}$} \\
\hline & & Bilgelik*(N=3) & \\
\hline
\end{tabular}




\begin{tabular}{|c|c|c|}
\hline \multirow[t]{17}{*}{ Diğer } & Koşulsuz kabul(N=3) & \multirow{2}{*}{$\begin{array}{l}\text { Mevlâna insanlara dil, din, ırk, cinsiyet ayrı- } \\
\text { mı yapmadan tüm insanlığa yol gösteriyordu. } \\
\text { (Ö4) }\end{array}$} \\
\hline & İyi niyet(N=2) & \\
\hline & Merhametli olma* $(\mathrm{N}=2)$ & $\begin{array}{l}\text { Planlarımda Türk büyüklerinin, kararlılı̆̆ı, } \\
\text { azmi ve merhametli oluşlarına değindim. } \\
\text { (Ö13) }\end{array}$ \\
\hline & Adalet $(\mathrm{N}=2)$ & \multirow{2}{*}{$\begin{array}{l}\text { Adaletli ve cesurlard,, vatan ve bayrak sevgi- } \\
\text { si, insan sevgisi temel özellikleriydi. (Ö16) }\end{array}$} \\
\hline & Empati(N=2) & \\
\hline & Paylaşımcı olma*(N=1) & $\begin{array}{l}\text { Çalışkan, dürüst, yardımsever ve paylaşım- } \\
\text { clydılar. (Ö9) }\end{array}$ \\
\hline & Başarı ve Azim*(N=7) & $\begin{array}{l}\text { Çok alçak gönüllü, insanlara üstten bakma- } \\
\text { yan, ilim ve bilimin gelişmesi için uğraşan, } \\
\text { çalışkan, azimli ve hırslı, Allah’tan başka } \\
\text { kimseden korkusu olmayan, inançlı, inanç- } \\
\text { ları çerçevesinde aklına koyduklarını yapan, } \\
\text { istikrarlı ve yönetme gücü olan kişilerdi. } \\
\text { (Ö18) }\end{array}$ \\
\hline & İman sahibi olma(N=5) & $\begin{array}{l}\text { Dini konuları önemsemeleri ve bu doğrultu- } \\
\text { da başarılı olmaları. (Ö8) }\end{array}$ \\
\hline & $\begin{array}{l}\text { Zeki ve ileri görüşlü } \\
\text { olma*(N=6) }\end{array}$ & $\begin{array}{l}\text { Keloğlan'ın zekiliği, güldürürken öğretmesi; } \\
\text { Mevlana'nın insan sevgisi; Nasrettin Ho- } \\
\text { ca'nın güldürürken düšündürmesi, Mehmet } \\
\text { Akif Ersoy'un zekiliği ve vatan sevgisini } \\
\text { işledim. (Ö23) }\end{array}$ \\
\hline & $\begin{array}{l}\text { Araştırmac1 ve meraklı } \\
\text { olma(N=3) }\end{array}$ & $\begin{array}{l}\text { İleri görüşlü, girişimci, meraklı, kararlı, } \\
\text { teşkilatçıydılar. (Ö20) }\end{array}$ \\
\hline & Sayg1 $(N=3)$ & \multirow{2}{*}{$\begin{array}{l}\text { Örnek ve modeldiler, azimliydiler, vatan ve } \\
\text { millet sevgisine sahiptiler. (Ö22) }\end{array}$} \\
\hline & Örnek olma $(\mathrm{N}=2)$ & \\
\hline & $\begin{array}{l}\text { Yenilikçi ve girişimci } \\
\text { olma*(N=2) }\end{array}$ & $\begin{array}{l}\text { Atatürk'ün öngörülü, yenilikçi, cesaretli } \\
\text { olma; vatanseverlik özellikleri vardı. }\end{array}$ \\
\hline & $\begin{array}{l}\text { Teşkilatçı ve karizmatik } \\
\text { olma(N=2) }\end{array}$ & $\begin{array}{l}\text { İnançları güçlüydü, naif ve saygılıydılar, } \\
\text { karizmatik liderlerdi. (Ö24) }\end{array}$ \\
\hline & İletişime açı olma(N=1) & \multirow{3}{*}{$\begin{array}{l}\text { Lider, iletişimi iyi, yönlendirebilen, vatanse- } \\
\text { ver, yenilikçi, farklı bakış açılarına sahip, in- } \\
\text { sanlara yol açan ve yol gösteren, sorumluluk } \\
\text { sahibi, güvenilir, iyi niyetli, dürüst, örnek ve } \\
\text { ilham kaynağı olma özelleri vardı. (Ö12) }\end{array}$} \\
\hline & Sorumluluk sahibi(N=1) & \\
\hline & $\begin{array}{l}\text { Naif ve güvenilir ol- } \\
\mathrm{ma}(\mathrm{N}=2)\end{array}$ & \\
\hline
\end{tabular}

*Uygulamalarda yer verilen Türk Büyüklerine ait özellikler.

Tablo 3 incelendiğinde Türk büyüklerine öğretmenler tarafından atfedilen özellikler görülebilir. Türk büyüklerinin bilinen özellikleri ile ilgili alınan cevaplar ise: Türk büyüklerimizle ilgili "Erdemli olma" özelliği en çok verilen cevaplar arasında olduğu görülmektedir. Tablo 1'de okul öncesi eğitimde ahlak kavramları denince akla en çok gelen cevap "Erdemli olma" cevabı ile örtüşmektedir. Bu sonuç; model alma yoluyla öğrenmenin önemi açısından bakıldığında okul öncesi eğitimi yararına kullanılabileceği gerçeği görülmektedir. 
Bununla beraber başarılı ve azimli olmak, iman sahibi olmak, zeki ve ileri görüşlü olmak, lider olma, örnek olma, araştırmacı ve meraklı olma en çok verilen cevaplar arasındadır. Bunun dışında katılımcılar tarafından Türk büyüklerinin; yenilikçi, teşkilatçı, girişimci, sorumluluk sahibi, karizmatik ve iletişimde iyi oldukları belirtilmiştir. Türk büyüklerinin genel özellikleri ile verilen cevaplar arasında uyum olduğu görülmektedir. Tablo 3 de uygulamalarda Türk büyüklerinin genel özelliklerinin planlarda yer alma durumunda ise; Erdemli olma özelliği [Vatanseverlik ( $\mathrm{N}=12)$; Alçak gönüllük ve hoşgörü $(\mathrm{N}=11)$; Sevgi $(\mathrm{N}=6)$; Cesaret ( $\mathrm{N}=6)$; Bilgelik $(\mathrm{N}=4)$; Bayrak sevgisi ( $\mathrm{N}=3)$; Maneviyat ( $\mathrm{N}=3)$; Çalı̧̧kanlık ( $\mathrm{N}=2)$; Paylaşımcı olma $(\mathrm{N}=1)$ ve Merhametli olma $(\mathrm{N}=1)$ ] en çok işlenen kavramdır. Ahlaki davranış kavramını içeren "Yardımlaşma(N=1) ve Üslup $(\mathrm{N}=1)$ " verilen cevaplar arasındadır. Bunun yanında "Zeki-Öngörülü-Yetenekli olma ( $\mathrm{N}=7$ ); Özgüvenli-Kararlı-Başarılı olma ( $\mathrm{N}=4)$; Bilimsel ve Yenilikçi ol$\mathrm{ma}(\mathrm{N}=3)$; Kahraman $(\mathrm{N}=2)$ ve Yetenekli olma $(\mathrm{N}=1)$ " s1k verilen cevaplar arasındadır. Ayrıca tablo 1'de okul öncesi dönemde ahlak eğitimine ilişkin verilen Erdemlilik kavramı ile Türk büyüklerinin Erdemlilik özeliği ve uygulamalar da yer verilen Erdemlilik özelliği uyum göstermektedir. Sonuçların doğrusal olduğu birbirini tamamladığı görülmektedir. Tablo 3' e bakıldığında 'zeki ve ileri görüşlü” olma özelliği uyuşurken, Tablo 1'de bu özelliğin ahlak kavramları içinde alınmamış olması bunun sadece karakter özelliği olarak ele alındığını göstermektedir. Ayrıca öğretmenlere Türk büyüklerini ahlaki olarak nasıl buldukları sorulduğunda "Ahlaki anlamda model olarak gördüklerini( $\mathrm{N}=13)$; mükemmel bulduklarını( $\mathrm{N}=4)$; T.B. ahlaka önem verdiklerini( $\mathrm{N}=2)$ ifade etmiştir. "Türk büyüklerine hayranlık duyulduğu, onların öncü şahsiyetler olmalarında ki sebeplerin merak edildiği, düşünceli ve cesur oldukları, kültürümüzü yansıttıkları, ender Müslümanlar olduğu, bilge ve faydalı oldukları, adaletli ve erdemli oldukları, onlara benzemek istendiği $(\mathrm{N}=7)$ " cevapları alınmıştır. Türk büyüklerine okul öncesi ahlak eğitiminde yer verilmeli midir diye sorulduğunda; 24 öğretmeninin 23'ü evet, 1'i hayır demiştir. Evet diyenlerin çoğunluğu neden olarak Türk büyüklerinin örnek olması $(\mathrm{N}=16)$; kavramların kalıcı olması $(\mathrm{N}=6)$; tarihe sahip çıkmak $(\mathrm{N}=2)$; topluma uygun olması $(\mathrm{N}=2)$; olumlu etkiler oluşturma $(\mathrm{N}=2)$;kahramana ihtiyaç duyulduğu $(\mathrm{N}=1)$ cevaplarını vermiştir. "Hayır" yanıtını veren 1 kişi ise neden olarak; çocuklara Türk büyüklerinin ilerleyen yaşlarda verilmesi gerektiğini belirtmiştir. Türk büyükleri ile ahlak eğitimi arasında nasıl bir ilişki kurulabilir sorusuna ise: 13 öğretmen "Örnek olarak ahlak eğitiminde Türk büyüklerine yer verilebiliriz" 6 öğretmen ahlak eğitimi ile "Pozitif bir ilişki kurabiliriz" cevaplarını vermiştir. Öğretmenlerin 
çoğunluğu Türk büyüklerinin örnek olarak verilebileceğini öngörmüştür. Ayrıca "Bilgim yok, drama ve hikâye ile ilişkilendirilebilir, ahlak eğitimine önem veriyorlardı" verilen diğer cevaplar arasındadır. Araştırma sürecinde öğretmenlerin Türk Büyüklerini farklı yöntem ve teknikler kullanarak etkinliklere dâhil etmeye çalıştıkları fark edilmiştir. Etkinliklerde kullanılan yöntem ve tekniklere yönelik görüşlerinden elde edilen veriler Tablo 4'te sunulmuştur.

Tablo 4: Önerilen (Kullanılan) Yöntem ve Teknikler

\begin{tabular}{|c|c|c|c|c|}
\hline Tema & Alt Tema & Kategori & Kod & Örnek Görüşler \\
\hline \multirow{11}{*}{$\begin{array}{l}\text { Ahlak } \\
\text { Eğitimi } \\
\text { ve Türk } \\
\text { Büyükleri }\end{array}$} & \multirow{11}{*}{$\begin{array}{l}\text { Yöntem ve } \\
\text { Teknikler }\end{array}$} & \multirow{11}{*}{$\begin{array}{l}\text { Ahlak } \\
\text { Eğitimi } \\
\text { Önerilen }\end{array}$} & $\operatorname{Drama}(\mathrm{N}=14)$ & \multirow[t]{2}{*}{$\begin{array}{l}\text { Oyun ve drama yöntemi, hikâye okuma, } \\
\text { model alma, sohbet etme yöntemleriyle } \\
\text { verilebilir. (Ö5) }\end{array}$} \\
\hline & & & Eğitsel oyun(N=9) & \\
\hline & & & Hikâye $(\mathrm{N}=8)$ & \multirow{2}{*}{$\begin{array}{l}\text { Hikâye okuma, oyun, Değerler eğitimi } \\
\text { dersi, görsel işitsel sunum ve materyal- } \\
\text { lerle ahlaki kavramlar verilebilir. (Ö3) }\end{array}$} \\
\hline & & & $\begin{array}{l}\text { Görsel işitsel } \\
\text { araç ve materyal- } \\
\text { ler( } \mathrm{N}=3)\end{array}$ & \\
\hline & & & $\begin{array}{l}\text { Gösteri-gösterip } \\
\text { yaptırma }(\mathrm{N}=2)\end{array}$ & $\begin{array}{l}\text { Drama, oyun gösteriler ile verilebilir. } \\
\text { (Ö9) }\end{array}$ \\
\hline & & & Model alma(N=2) & \multirow{2}{*}{$\begin{array}{l}\text { Aile işbirliği yapılmalı. Çocuk bu kav- } \\
\text { ramları gerçek hayatta uygulayabilmeli. } \\
\text { (Ö20) }\end{array}$} \\
\hline & & & Aile işbirliği( $(\mathrm{N}=2)$ & \\
\hline & & & $\begin{array}{l}\text { Örnek Türk bü- } \\
\text { yükleri } \\
(\mathrm{N}=1)\end{array}$ & $\begin{array}{l}\text { Hikâyeler, drama, video ve çizgi filmler, } \\
\text { empati yöntemi kullanılabilir. Türk } \\
\text { büyükleri örnek gösterilerek kavramlar } \\
\text { öğretilebilir. (Ö1) }\end{array}$ \\
\hline & & & $\begin{array}{l}\text { Örnek olay ince- } \\
\text { lemesi } \\
(\mathrm{N}=1)\end{array}$ & $\begin{array}{l}\text { Hayatta yaşanmış örnekler ile, görseller, } \\
\text { drama ve canlandırma yöntemleri kulla- } \\
\text { nılabilir. (Ö23) }\end{array}$ \\
\hline & & & $\begin{array}{l}\text { Sohbet ve Anla- } \\
\operatorname{tim}(\mathrm{N}=3)\end{array}$ & $\begin{array}{l}\text { Drama, anlatım, oyun, akran eğitimi, } \\
\text { görsel işitsel videolar. (Ö2) }\end{array}$ \\
\hline & & & Diğer(N=13) & $\begin{array}{l}\text { Bunun için ahlak eğitiminin okul öncesi } \\
\text { dönemde çocuk açısından önemi, amacı, } \\
\text { tarihi seyri, çocuk gelişim alanları ve } \\
\text { gelişim basamakları göz ardı edilmeden } \\
\text { kavramlar verilmeli. (Ö4) }\end{array}$ \\
\hline \multirow{6}{*}{$\begin{array}{l}\text { Ahlak } \\
\text { Eğitimi } \\
\text { ve Türk } \\
\text { Büyükleri }\end{array}$} & \multirow{6}{*}{$\begin{array}{l}\text { Yöntem ve } \\
\text { Teknikler }\end{array}$} & \multirow{6}{*}{$\begin{array}{l}\text { Türk } \\
\text { büyükleri } \\
\text { işlenirken } \\
\text { önerilen }\end{array}$} & $\operatorname{Drama}^{*}(\mathrm{~N}=22)$ & \multirow{2}{*}{$\begin{array}{l}\text { Drama, oyun, sanat etkinliği, görsel ve } \\
\text { işitsel araçlar kullandım. Ayrıca Mehmet } \\
\text { Akif'i konu alan hikâye yazdım ve } \\
\text { okudum. (Ö21) }\end{array}$} \\
\hline & & & $\begin{array}{l}\text { Okul öncesi etkin- } \\
\text { likleri* }(\mathrm{N}=15)\end{array}$ & \\
\hline & & & $\begin{array}{l}\text { Görsel işitsel } \\
\text { araç ve materyal- } \\
\text { ler* }(\mathrm{N}=14)\end{array}$ & $\begin{array}{l}\text { Sunumlar ve görselleri, slaytları, oyun, } \\
\text { drama, müzik, Türkçe dil ve sanat etkin- } \\
\text { liklerini kullandım. (Ö23) }\end{array}$ \\
\hline & & & $\begin{array}{l}\text { Eğitsel } \\
\text { Oyun* }(\mathrm{N}=7)\end{array}$ & \multirow{2}{*}{$\begin{array}{l}\text { Anlatım, sohbet, görsel işitsel sunumlar, } \\
\text { kuklalar, soru cevap, tekrar yöntemlerini } \\
\text { kullandım. (Ö22) }\end{array}$} \\
\hline & & & Soru cevap* $(\mathrm{N}=5)$ & \\
\hline & & & $\begin{array}{l}\text { Gösteri-gösterip } \\
\text { yaptırma*(N=3) }\end{array}$ & $\begin{array}{l}\text { Gösteri, video ve belgesel, sanat etkinli- } \\
\text { ği, drama kullandım. (Ö2) }\end{array}$ \\
\hline
\end{tabular}




\begin{tabular}{ll} 
Anlatım*(N=2) & $\begin{array}{l}\text { Anlatım, drama, soru cevap ve müzik } \\
\text { kullanılmalıdır. (Ö7) }\end{array}$ \\
\hline $\begin{array}{l}\text { Araştırma ince- } \\
\text { leme } \\
*(\mathrm{n}=2)\end{array}$ & $\begin{array}{l}\text { Drama, proje araştırması, oyun, şarkı, } \\
\text { kukla tiyatrosu, sanat etkinlikleri kulla- } \\
\text { nılmalıdır. (Ö15) }\end{array}$ \\
\hline $\begin{array}{l}\text { Örnek olay ince- } \\
\text { lemesi }\end{array}$ & $\begin{array}{l}\text { Drama, soru cevap, hikâye anlatma ve } \\
\text { örnek olaylar kullanılmalıdır. (Ö5) }\end{array}$ \\
\hline Deney $(\mathrm{N}=1)$ & $\begin{array}{l}\text { Gösterip yaptırma, video, görsel ve } \\
\text { drama kullandım. Mevlâna haftasında } \\
\text { deney yaptım. (Ö5) }\end{array}$ \\
\hline Tekrar*(N=1) & $\begin{array}{l}\text { Yaparak ve yaşayarak öğretilmeli. } \\
\text { Drama, beyin fırtınası, soru cevap yön- } \\
\text { temleri kullanılmalı. }\end{array}$ \\
\hline Beyin Fırtınası & $\begin{array}{l}\text { İstasyon sistemi ile çocuklara Türk } \\
\text { Büyükleri tanıtılabilir. (Ö17) }\end{array}$ \\
\hline İstasyon $(\mathrm{N}=1)$ &
\end{tabular}

*Türk büyükleri işlenirken kullanılan yöntem ve teknikler

Tablo 4 incelendiğinde okul öncesi eğitim öğretmenleri ahlak kavramları verilirken en çok önerdiği yöntem ve teknikler sırasıyla "Drama, eğitsel oyun, hikâye okuma, görsel-işitsel cihaz ve materyaller, gösteri-gösterip yaptırma" yöntemlerinin kullanılabileceğini ifade etmiştir. Bunun yanında öğretmenlerce; model alma, sohbet, aile işbirliği, örnek Türk büyükleri, örnek olay incelemesi, düz anlatım, işbirlikli öğrenme kullanılabilecek diğer yöntemlerin arasında gösterilmiştir. Ahlaki kavramların; empati kavramı kullanılarak ve kavramın önem ve amacına dikkat edilerek, gelişim alan ve basamaklarına göre, kavrama uygun okul öncesi etkinlikleri ile; din eğitimi ile, öğretmenler tarafindan hizmet içi eğitimlerin alınarak ve firsat eğitimi (Diğer: $\mathrm{N}=13$ ) ile verilebileceği öngörülmüştür. Yine Türk büyükleri işlenirken önerilen yöntem ve teknikler için en çok verilen cevaplar sırasıyla "Drama tekniği, okul öncesinde yapılan etkinlikler, görsel işitsel cihaz ve materyaller, eğitsel oyun, soru cevap, gösteri-gösterip yaptırma iken; anlatım, araştırma inceleme, örnek olay incelemesi, deney, tekrar, beyin firtınası, istasyon tekniklerinin de önerildiği görülmüştür. Türk büyükleri işlenirken uygulamalarda kullanılan yöntem ve teknikler için en çok belirtilen "Drama $(\mathrm{N}=16)$ iken bu sonucu sırasıyla; okul öncesi etkinlikleri $(\mathrm{N}=14)$, görsel işitsel cihaz ve materyaller $(\mathrm{N}=14)$, gösteri-gösterip yaptırma $(\mathrm{N}=7)$, anlatım $(\mathrm{N}=7)$, eğitsel oyun $(\mathrm{N}=3)$, soru cevap $(\mathrm{N}=1)$, tekrar $(\mathrm{N}=1)$, beyin firtınası $(\mathrm{N}=1)$, sohbet $(\mathrm{N}=1)$, araştırma inceleme $(\mathrm{N}=1)$ teknikleri takip etmiştir. Tablo 4' de kategoriler karşılaştırıldığında; Ahlak kavramları ve Türk büyükleri işlenirken önerilen yöntem ve teknikler, öğretmenlerin Türk büyükle- 
rini planlarında işlerken kullandıkları yöntem ve tekniklerin farklılık gösterdiği sonuçlar: Araştırmaya katılan öğretmenlerden çoğu Türk büyüklerini ve ahlaki kavramları etkinliklere "Drama ve Eğitsel oyun" ile dâhil edilebileceğini önermektedir ancak gerçekte Türk büyüklerini anlatırken drama etkinliğini kullanan öğretmen sayısı daha azdır. "Örnek olay incelemesi” de önerilirken kullanılmayan teknikler arasındadır. Aynı zamanda Türk büyükleri işlenirken önerilen "Okul öncesi etkinlikleri ile öğretim, Soru cevap ve Araştırma inceleme yöntemleri önerilirken, öğretmenler tarafından daha az kullanıldığı tespit edilmiştir. "Beyin firtınası, İstasyon ve Deney" yöntem ve teknikleri ise Türk büyükleri işlenirken önerilmiş fakat öğretmenler tarafindan hiç kullanılmamıştır. $\mathrm{Bu}$ sonuçlar bize düşünülen bazı tekniklerin gerçekte sınıflarda kullanılmadığını göstermektedir. Ayrıca "Gösterip yaptırma, Anlatım ve Görsel işitsel araç ve materyaller" katılımcılar tarafindan daha az önerilirken öğretmenler tarafından daha fazla kullanılmaktadır. Verilen cevaplar düşünüldüğünde bu durum kullanılan yöntemlerin etkili olmamasından ziyade, etkinlik esnasında çok fazla kullanıldığı için önerilecek kadar farklı görülmediğini göstermektedir. Bunun dışında "Model alma, Aile işbirliği, İşbirlikli öğrenme" ahlaki kavramları verirken kullanılabilecek teknikler arasında belirtilmişken, Türk büyükleri işlenirken önerilen ve kullanılan teknikler arasında hiç yer almadığı görülmüştür. "Sohbet ve Tekrar" yöntemleri ise önerilen ve kullanılan yöntemler arasındadır.

Öğretmenlerin ahlak eğitimi için sınıflarında geliştirmeyi düşündükleri Türk Büyükleri merkezi düşüncesine sahip oldukları fark edilmiştir. Oluşturulmak istenen merkeze yönelik özellikleri içeren veriler Tablo 5'te sunulmuştur.

\begin{tabular}{|c|c|c|c|}
\hline Tema & Alt Tema & Kod & Örnek Görüşler \\
\hline \multirow{5}{*}{$\begin{array}{l}\text { Türk } \\
\text { büyükleri } \\
\text { merkezi }\end{array}$} & \multirow{5}{*}{ Görüşler } & $\begin{array}{l}\text { Sabit bir merkez } \\
\text { kurulmalı }(\mathrm{n}=14)\end{array}$ & $\begin{array}{l}\text { Kendi ecdadımızı örnek almak için unutup başkalaş- } \\
\text { mamak için daha fazla örnek alarak eğitime entegre } \\
\text { edilerek Türk büyükleri merkezi eklenmelidir. (Ö18) }\end{array}$ \\
\hline & & $\begin{array}{l}\text { Geçici ilgi merkez- } \\
\text { leri kurulmalı(n=7) }\end{array}$ & $\begin{array}{l}\text { Çok güzel ve etkili olacağını düşünüyorum. Her hafta } \\
\text { farklı bir Türk büyüğüne yer verilebilir. Bu onların } \\
\text { merak duygusunu tetikler. (Ö17) }\end{array}$ \\
\hline & & $\begin{array}{l}\text { Okulda merkez } \\
\text { oluşturulmalı }(\mathrm{n}=3)\end{array}$ & $\begin{array}{l}\text { Çocuklar kendi büyüklerini tanımalı ve bunlarla } \\
\text { ilgili erken dönemde fikir sahibi olmalı. Okulun bir } \\
\text { bölümüne konmalı, Büyükler kahramanlık edebiyat } \\
\text { gibi bölüm bölüm ayrılmalı. (Ö5) }\end{array}$ \\
\hline & & $\begin{array}{l}\text { Var olan merkezlere } \\
\text { eklenmeli }(n=2)\end{array}$ & $\begin{array}{l}\text { Küçük sınıflar için drama merkezine ek yapılabilir } \\
\text { yada pano hazırlanabilir. (Ö6) }\end{array}$ \\
\hline & & $\begin{array}{l}\text { T.B. merkezi olma- } \\
\text { malı }(\mathrm{n}=1)\end{array}$ & $\begin{array}{l}\text { Gerekli değildir çünkü küçük yaşın bu kazanımları iler- } \\
\text { leyen dönemde alması gerektiğini düşünüyorum. (Ö4) }\end{array}$ \\
\hline
\end{tabular}




\begin{tabular}{lll}
\hline \multirow{2}{*}{ Materyal } & $\begin{array}{l}\text { Görsel işitsel cihaz } \\
\text { ve materyaller: } \\
(\mathrm{n}=22)\end{array}$ & $\begin{array}{l}\text { Görsel, resim, ses kayıtları, maketler, varsa eserleri } \\
\text { merkeze konabilir. (Ö21) }\end{array}$ \\
\cline { 2 - 3 } & Kostümler $(\mathrm{n}=6)$ & $\begin{array}{l}\text { Drama için döneme uygun kostümler konulabilir. } \\
(\text { Ö15) }\end{array}$ \\
\cline { 2 - 3 } & Oyuncak $(\mathrm{n}=3)$ & Oyuncaklar, maketler olabilir. (Ö7) \\
\hline
\end{tabular}

Tablo 5 incelendiğinde okul öncesi kurum ve sinıflarda Türk büyükleri merkezi kurulmalı cevabını veren öğretmen sayısı 22'dir. Aksini söyleyen 1 öğretmen olmuştur. TB merkezi kurulmalı diyenlerin görüşleri ise şu yöndedir: "S1nıfa sabit Türk büyükleri merkezi” olması gerektiğini söylemiş ve sebep olarak da "Kalıcı öğrenmenin gerçekleşmesi” olduğunu belirtmiştir. "Geçici ilgi merkezleri kurulmalı" cevabını veren öğretmenler bu merkezlerin "Verilecek olan kavramla ilişkili kurulması ve belirli gün ve haftalar ile ilişkilendirilmesini”" öngörmüştür. "Okulda merkez kurulmalı; okulda ortak amaca hizmet eden ve herkesin görebileceği bir yerde T.B. merkezi olması gerekir"; "Var olan merkezlere eklenmesi" ile ilgili verilen cevaplarda ise "Kitap ve dramatik oyun merkezine ekleme" yapılabileceği fikri belirtilmiştir. "Sınıfta geçici merkez olmalı" cevabını veren öğretmenler sınıfta var olan merkezlere de ekleme yapılabileceği fikrini öngörmüştür. "Türk büyükleri merkezi olmamalı" diyen 1 öğretmen ise "Bu kazanımların ilerleyen yaşlarda alınması gerektiğini” sebep göstermiştir. Kurulacak Türk büyükleri merkezine "Görsel işitsel cihaz ve materyaller, kostümler, boya ve artık materyaller, oyuncaklar” bırakılabileceği katılımcılar tarafından öngörülmüştür.

\section{Sonuç ve Tartışma}

Çalışmanın sonuçlarına göre devlet büyüklerini, tasavvuf büyüklerini, halk kahramanlarını, şair-yazarlar ile bilim alanında öncü birçok ismi Türk büyüğü olarak niteleyen öğretmenlerin bu kişilerle ilişkili ahlak eğitimi denildiğinde aklına ilk olarak; erdemlilik, iman sahibi olma, azim ve başarı, basiretli olma, örnek olma gibi kavramlar gelmektedir. Öğretmenler okul öncesi ahlak eğitiminde verilebilecek ilk üç kavram olarak en çok "erdemlilik, ahlaki davranışlar ve ahlaki kurallar" cevaplarını belirtmiştir. Bunun sebebi olarak, okul öncesi eğitim sınıflarında küçük çocukların sözel ve fiziksel saldırganlık, diğer çocukların ve öğretmenin haklarına engel olmaya yol açacak olumsuz davranışlar sergileyebildikleri düşünülmektedir (Uysal, Altun ve Akgün, 2010). Alınan ce- 
vaplar literatürde yer alan diğer araştırmalarla benzerlik göstermektedir (Kolaç ve Karadağ, 2012; Erkuş ve Yazar, 2013; Köse ve Uzun, 2017; Ogelman ve Sarıkaya, 2015; Kozikoğlu, 2018). Okul öncesi eğitim programında değerlere yer verilme durumuna bakıldığında ise "sorumluluk" değer kavramına çok fazla yer verildiği, bunu sırasıyla saygı, dayanışma, güven, sevgi, hoşgörü, özgürlük, eşitlik, dostluk ve adalet değerlerinin izlediği görülmüştür (Aral ve Kadan, 2018).

Araştırmada alınan cevapların (Ahlaki kurallar, erdemlilik ve ahlaki davranış), programda yer alan kavramlarla da ilişkili olduğu görülmektedir. Buna ek olarak okul öncesi eğitim programında en çok sorumluluk kavramına yer verilmiştir. Buna karşın öğretmenlerden sadece birinin sorumluluk kavramına değinmiş olması başka bir araştırmada alınan cevaplar arasında sorumluluk kavramının daha fazla yer alması (Ogelman ve Sarıkaya,2015) ahlaki kavramlara yer verilme durumunun içinde bulunulan yaşantı, çevre şartları, sınıfta karşılaşılan durumlar, değer yargıları gibi değişkenlerden etkilendiği sonucu öngörülür. $\mathrm{Bu}$ sonuç, tüm değerlerin anlaşılır biçimde eşit olarak programla bütünleştirilerek sürece dâhil edilmesi gerektiğini göstermektedir(Aral ve Kadan, 2018). Millî Eğitiminin genel amaçlarında yer alan "Türk milletinin millî, ahlâkî, insanî, manevî ve kültürel değerlerini benimseyen, koruyan ve geliştiren” (MEB, 2013) ifadesi yer almasına karşın okul öncesi eğitim programında millî değer ve kültür yansımalarının beklendiği kadar olmadığı görülmüştür (Aral ve Kadan, 2018).

Eğitimin kesintisiz bir süreç olduğu düşünüldüğünde, çocukların gelecekteki sosyal yaşantılarının olumsuz etkilenmemesi ve bu nedenlerle akademik zorluklarla karşılaşılmaması için erken dönemlerden itibaren ahlaki değerlere odaklanılması gerektiği söylenebilir (Balıkçı, 2016). Erken dönemlerden başlanarak ahlaki değer ve yargılar için yapılacak her türlü çalışmanın, çocukların sonraki yaşamları için istendik yönde davranış kazanmalarına yardımcı olacağ1 düşünülmektedir. Bu nedenle ahlaki yarg1 ve kavramların programda ve etkinliklerde açıkça ifade edilmesi sonraki eğitim kademeleri için önemli görülmektedir. İlköğretim ve ortaöğretim programı kapsamında yapılan araştırmada programlarda değerlere açıktan vurgunun yapıldığı görülmüştür (Özer ve Çam Aktaş, 2019).Özellikle vurgu yapılan değerler; "millî, manevi, insani değerler, çevresel değerler ve işbirliği”" olmuştur. Bu da ilerleyen eğitim kademelerine hazırlık olması bakımından programın tekrar ele alınarak düzenlenmesini gerekli kılmaktadır. Görüşlerden; öğretmenlerin birçoğunun müfredatta yer verilen şeklin dışında ahlak eğitimi ile ilgili herhangi aktif program uygulamadığı 
anlaşılmaktadır. Ancak öğretmenlerin büyük bir çoğunluğunun ahlak eğitimi ile ilgili etkinliklere yer vermeye çalıştığı hissedilmiştir.

Araştırmacılar (Tillman \& Hsu, 2000; Uyanık Balat ve arkadaşları, 2012) okul öncesi dönemde çocuklara evrensel değerlerin (saygı, sevgi, barış, dürüstlük, doğayı sevme, sorumluluk, işbirliği, barış, hoşgörü vb.) öğretilmesi gerektiğini ifade etmişlerdir. İlgili değerlerin nasıl ve hangi yöntemler kullanılarak verileceği öğretmenlere sorulduğunda en çok kullanılan ve tavsiye edilen ilk üç cevap şöyledir: İlk sırada drama yöntemi vardır. Bu yöntemin ilk sırada olması; ahlaki kavramların bu yolla daha etkin verilebileceği öngörüsü, literatür sonuçları ile karşılaştırıldığında doğru bir yaklaşım biçimi olduğu desteklenmektedir. Bunun yanında sadece drama değil çocuklarında kendilerinden bir şeyler kattığ yaratıcı drama yönteminin de kullanılabileceğini gösteren kaynaklar bulunmaktadır (Kaya, Günay ve Aydın, 2016; Kaya ve Antepli, 2018). Eğitsel oyunun, drama tekniğinden sonra öğretmenler tarafindan tercih edildiği görülmüştür bu durum verilen cevaplar arasında daha fazla yer alması, okul öncesi dönem ahlaki eğitime katkı sunacağını aktaran diğer araştırmalarla paralellik göstermektedir. Eğitsel oyun; çocuğu birçok yönden geliştirdiği gibi aynı zamanda sosyal ilişkiler kurulmasına yardım ederek çocukta değer kavramının oluşmasına katkı sağlamaktadır. Akranlarıyla sosyalleşme şansı bulan çocuklar böylece saygı, nezaket, mutluluk, yardımseverlik, hoşgörü, sorumluluk, sabır, ait olma, duyarlılık, cesaret, adalet ve iyilik gibi değerleri hiçbir zorlama ve baskı olmadan kendi kurdukları ilişkiler yoluyla kazanmış olur (Gündüz, Aktepe, Uzunoğlu ve Gündüz, 2017). Ayrıca hikâye okuma tekniğinin yine verilecek ahlaki eğitime katkı sunacağı ve çocuklara sosyal değerler, etik değerler kazandıracağ öngörüsü yapılan araştırmalarla ile paralellik göstermektedir (Ural, 2013, s. 47-48). Türk büyüklerini ve özelliklerini çocukların zihinlerinde somutlaştırarak ahlaki kavramların pekiştirilmesini kolaylaştıracak hikâye, canlandırma ve oyunlaştırma gibi tekniklere yer veren etkinliklerin kullanılmasının daha doğru olacağ1 düşünülmektedir (Balıkçı, 2016). Araştırmada öğretmenler tarafindan çoğunlukla önerilen drama, oyun ve hikâye okuma yöntemlerinin kullanılması diğer araştırmalarda karşılaşılan sonuçlar arasındadır (Bartan, 2018; Kozikoğlu, 2018; Köse ve Uzun, 2017). Ayrıca araştırmacıların, görsel-işitsel olarak desteklenmiş hikâyelerin de kavramlara uygun olarak zenginleştirilmiş örneklerle pozitif ilişki kurularak okul öncesi dönem çocuklarının gelişim özelliklerine uygun biçimde kullanılabileceğini bildikleri görülmüştür. Özellikle öğretmenler tarafından drama yönteminin sıklıkla vurgulanması ahlak eğitiminin yaşantılara dayalı olarak Türk büyükleri ile ilişkilendirilerek çocuklara verilmesini ko- 
laylaştıracağı düşünülmüştür. Bu durum diğer bir araştırma ile uyum içindedir (Daysal-Ersoy, 2011). Ayrıca öğretmenlerin önerdiği ve uygulamaya çalıştığı bu tür tekniklerin yapılan araştırmalarda kalıcılık gösterdiği, Türk büyüklerini konu alan ahlak eğitiminde uygulanabileceği de görülmüş̧ür (Ceran, 2015; Daysal-Ersoy, 2011; Demircioğlu, 2007).

Öğretmenlerin görüşlerinden Türk büyüklerinin kişilik özellikleri ve ahlaki yapılarının model alınması gerektiğine inandıkları belirlenmiştir. Nitekim Türk Millî Eğitiminin genel amaçlarında yer alan "Türk milletinin millî, ahlâkî, insanî, manevî ve kültürel değerlerini benimseyen, koruyan ve geliştiren bireyler yetiştirme esası" doğru rol modeller sunmayı zorunlu kılmaktadır. Bu araştırmada ünlü Türk büyüklerinin ahlak eğitiminde yer alma durumu ile ilgili öğretmen görüşleri ele alınılırken farklı katılımcı gruplarıyla yapılan çalışmalarında yer aldığ1 görülmektedir (Karakaş, 2015; Kolaç ve Karadağ, 2012). Araştırma sonuçlarına bakıldığında; öğretmen adaylarının "Türk Toplumuna ait kültür, gelenek ve göreneklerin, ulusal değerlerin öğretilmesi gerektiğini; maddi manevi unsurların, tarihi kahramanların ve önder olmuş şahsiyetlerin değerler eğitiminde yer verilmesi gerektiğini belirterek ahlaki değerlere, millî ve kültürel değerlere vurgu yaptıkları fark edilmiştir. Ayrıca değerler eğitimi ile Hz. Mevlana, Âşık Veysel gibi şahsiyetlerin evrensel değerlerini konu alan öğütlerin, yaşantı biçimlerinin, deneyimlerinin çocukların düzeyine göre indirgenerek öğretilmesine yönelik yapılan araştırmalarla nesilden nesille kültür aktarımını sağlayabileceği düşünülmektedir (Karakaş, 2015; Kolaç ve Karadağ, 2012).

Araştırma sonuçlarından bir diğeri de Türk büyükleri merkezlerinin oluşturularak sınıflara yerleştirilmesi yönündedir. Bu kapsamda, geçmiş tarihimize yönelik materyal yönünden zengin eğitim ortamlarının tasarlanmasının bu süreci destekleyeceğini belirten öğretmenler ayrıca bununla ilgili olarak okul ve s1nıflarda Türk Büyükleri merkezinin kurulmasını öngörmüşlerdir. Üner 2011'de yaptığ çalışmasında, okullardaki materyal ve fiziksel donanım yetersizliğinin verilen değerler eğitimini zorlaştırdığını ifade etmiştir. Mevcut araştırma sonuçları bu çalışmayı destekler niteliktedir.

Sonuç olarak ahlak eğitimine yönelik etkinlik ve uygulamalarla istenilen hedeflere ulaşılması için; ilgili yaş grubuna grubunun ilgi ve ihtiyaçları dikkate alınarak eğitim içeriklerinin geliştirilmesi gerekir. Eğitim kademesi gözetmeksizin kendi millî ve manevi değerlerimizin öne çıktığı içerisinde evrensel değerlerden başta barışı, hoşgörüyü, sevgiyi, saygıyı ve dürüstlügü konu alan uygulamalara yer verilmesi önemlidir. Hedef kitlenin ahlaki kavram ve değer- 
leri içselleştirilmesini kolaylaştıracak yaşantıya dayalı yöntem ve tekniklerin eğitimciler tarafindan tercih edilmesi ise doğru olacaktır. Toplumda ahlaki anlayışın oluşması, belli bir zaman alabileceğinden, okul öncesi dönemde verilecek olan ahlak eğitimi sağlam bir temel atılması adına son derece önemlidir. Bahsedilen ahlaki kavram ve özelliklerin Türk büyükleri ile ilişkilendirilerek verilebileceği, bu durumun program da ki "millî değer ve kültür yansımaları" eksikliğini giderebileceği öngörülmektedir. Ahlak eğitimi tarihteki büyük şahsiyetler ile ilişkilendirildiği zaman, Türk büyüklerinin sahip olduğu özelliklerin değer ve ahlak eğitimine önemli katkılarının olabileceği görülebilir. Değerlerin geçmişten bugüne nasıl değiştiği, değişme nedenleri, geçmişteki önemli şahsiyetler, olaylar ve yaşantılar çocukların ahlaki değer oluşturmalarında önemli unsurlardır. Bu durum yapılan araştırmada okul öncesi eğitimde verilen ahlak eğitiminin çocuklarda kalıcılık gösterdiği ve Türk büyüklerinin özelliklerinin çocuklar tarafından içselleştirdiği sonuçları ile uyum içerisindedir (Daysal-Ersoy, 2011). Tarihte yer almış Türk büyükleri ile hem mevcut değerlerin aktarımı gerçekleştirilebilir hem de çocuklara kendi kişisel değerlerini oluşturmaları yönünde önemli firsatlar verilmiş olur. Bu açıdan bakıldığında, tarihteki Türk büyüklerinin ahlak eğitimine konu edilmesi çocuklardan beklenen vatandaşl1k becerilerinin geliştirilmesi ve kültür aktarımı açısından eğitimcilere kolaylıklar sağlayabilir. Araştırmada tartışılan tüm bu durumlar; okul öncesi dönemde verilen ahlak eğitiminin önemini bir kez daha vurgularken, sihirli yıllar olan okul öncesi dönem eğitiminin kıvanç duyduğumuz büyük şahsiyetler ile ilişkilendirilebileceğini göstermektedir.

\section{Kaynakça}

Akalın, Ş. H. (2009). Türkçe Sözlük. Türk Dil Kurumu.

Akbaş, O. (2008). Değer eğitimi akımlarına genel bir bakış. Değerler Eğitimi Dergisi, 6(16), 9-27.

Aral, N. ve Kadan, G. (2018). 2013 Okul öncesi eğitim programının değerler eğitimi bağlamında incelenmesi. Erken Çocukluk Çalışmaları Dergisi, 2(1), 113-131.

Arslanoğlu, İ. (2016). Türk değerleri üzerine bir değerlendirme. http://devlet.com. tr/makaleler/y189turkdegerlerıuzerınebırdegerlendırme2.html

Aydın, M. Z. (2003). Ahlak ögrretiminde örnek olay incelemesi. Nobel Yayıncılık.

Balat, G. U. (2006). Okullarda neden değerler eğitimi çalışmaları. Illköğretmen Eğitimci Dergisi, 2, 14-16.

Balat, G. U. ve Dağal A. B. (2006). Okul öncesi dönemde değerler eğitimi etkinlikleri. Kök Yayıncılık. 
Balıkçı, G. N. (2016). Erken çocukluk döneminde değerler ve ahlak eğitiminin yeri ve önemi. Eğitimde Gelecek Arayışlarl: Dünden Bugüne Türkiye'de Beceri Ahlak ve Değerler Ĕgitimi Uluslararası Sempozyumu (16-18 Nisan/Bartın), Atatürk Araştırma Merkezi Yayınları, Ankara, 1, 105-106.

Bartan, S. (2018). Okul öncesi öğretmenlerinin değerler ve değerler eğitimi hakkındaki görüşleri ile sınıf içi uygulamalarının incelenmesi (Yayımlanmamış yüksek lisans tezi). Dumlupınar Üniversitesi, Eğitim Bilimleri Enstitüsü, Kütahya.

Bushman, B.J. \& L. R. Huesmann (2006). Short term and long term effects of violent media on aggression in children and adults. Archives of Pediatrics \& Adolescent Medicine, 160, 348-352.

Ceran, D. (2015). Çocuklara rol model olması bakımından millî mücadele kahramanları ve edebî eserlere yansıması: "Kurtuluşun kahramanları" kitap dizisi örneği. Tarih Okulu Dergisi, 24, 135-157.

Cooper, D. (2014). Character education: A study of an elementary school leadership Academy (Yayımlanmamış doktora tezi). Wilmington University, USA.

Corbin, J., \& Strauss, A. (2008). Strategies for qualitative data analysis. Basics of Qualitative Research. Techniques and procedures for developing grounded theory (3rd ed.). Thousand Oaks, Sage.

Daysal-Ersoy, D. (2011). Erken çocukluk döneminde sosyo-kültürel eğitim: ünlü Türk büyükleri (Yayımlanmamış yüksek lisans tezi). Sakarya Üniversitesi, Eğitim Bilimleri Enstitüsü, Sakarya.

Demircioğlu, İ. H. (2007). Tarih öğretiminde öğrenci merkezli yaklaşımlar. Anı Yayıncilik.

Demircioğlu, İ. H. ve Tokdemir, M. A. (2008). Değerlerin oluşturulma sürecinde tarih eğitimi: Amaç, işlev ve içerik. Değerler eğitimi dergisi, 6(15), 69-88.

Egan, K. (1988). Teaching as story telling an alternative approach to teaching and the curriculum. Routledge.

Erkuş, S. ve Yazar, T. (2013). Okul öncesi öğretmenlerinin okul öncesi eğitim programındaki değerler eğitimine ilişkin görüşlerinin değerlendirilmesi. Dicle Üniversitesi Ziya Gökalp Eğitim Fakültesi Dergisi, 20, 196-211.

Gündüz, M., Aktepe, V., Uzunoğlu, H., Gündüz, D. D. (2017). Okul öncesi dönemdeki çocuklara eğitsel oyunlar yoluyla kazandırılan değerler. MSKU Ĕgitim Fakültesi Dergisi. 4(1), 62-70.

Karakaş, H. (2015). Değerler eğitimi etkinliklerinin okul öncesi öğretmenlerine göre değerlendirilmesi: Nitel bir çalışma. Dünden Bugüne Türkiye'de Beceri, Ahlak ve Değerler Ĕ̆itimi Uluslararası Sempozyumu (Bartın), 1, 623-624.

Karataş, E. (2014). Çocuk edebiyatında "karakter" kavramı. Muğla Sıtkı Koçman Üniversitesi Sosyal Bilimler Enstitüsü Dergisi, 33, 60-79. 
Kaya, Y., ve Antepli, S. (2018). Okul Öncesi Dönemde Yaratıcı Drama Yoluyla Değerler Eğitimi. Yaratıcı Drama Dergisi, 13(2), 237-250.

Kaya, Y., Günay, R. ve Aydın, H. (2016). Okul öncesi eğitimde drama yöntemi ile işlenen değerler eğitimi derslerinin farkındalık düzeyi üzerindeki etkisi. Sakarya Üniversitesi Ĕ̌itim Dergisi, 6(1), 23-37.

Kolaç, E. ve Karadağ, R. (2012). Türkçe öğretmeni adaylarının “değer” kavramına yükledikleri anlamlar ve değer sıralamaları. Ilköğretim Online, 11(3), 762777

Kozikoğlu, İ. (2018). Okul öncesi öğretmenlerinin değerler eğitimine ilişkin tutum ve görüşlerinin incelenmesi. Uluslararası Türkçe Edebiyat Kültür Eğitim (TEKE) Dergisi, 7(4), 2698-2720.

Köse, A., ve Uzun, M. (2017). Okul öncesi eğitimde değerler eğitiminin uygulanmasına yönelik öğretmen görüşleri. Bayburt Eğitim Fakültesi Dergisi, 12(23), 305-338.

Krippendorff, K. (2013). Commentary: A dissenting view on so-called paradoxes of reliability coefficients. Annals of the International Communication Association, 36(1), 481-499.

MEB (2013). Millî Eğitim Bakanlığı okul öncesi eğitim programı. http://docplayer. biz.tr/895440-T-c-millî-egitim-bakanligi-talim-ve-terbiye-kurulu-baskanligi-konu-okul-oncesi-egitim-programı.html.

Miles, M. B., Huberman, A. M., \& Saldana, J. (2014). Qualitative data analysis: A methods sourcebook. 3rd. ed: Thousand Oaks, Sage.

Ogelman, H. G. ve Sarıkaya, H. (2015). Okul öncesi eğitimi öğretmenlerinin değerler eğitimi konusundaki görüşleri: Denizli ili örneği. Sakarya Üniversitesi Eğitim Fakültesi Dergisi, (29), 81-100.

Özer, M. ve Çam Aktaş, B. (2019). Değerler eğitimi devamlılığı: okul öncesi eğitim programından hayat bilgisi öğretim programına. Illkögretim Online, 18(1), 389-405.

Patton, M. Q. (2014). Nitel araştırma ve değerlendirme yöntemleri. Pegem Akademi.

Sagiv, L. (2002). Vocational interests and basic values. Journal Career Assess. $10(2), 233-257$.

Sar1, İ. (2018). Türklerde ahlak: Türklerde ahlak demek namus demektir. Nokta e-kitap.

Tillman, D. G. \& Hsu, D. (2000) Living Values Activities for Children Ages 3-7 (Deerfield Beach, FL, HCI).

Ural, S. (2013). Çocuk edebiyatı. Eğiten Kitap. 
Uyanık Balat, G., Yalçın, A., Yemenici, F., Sabancı, H., Kalaycı, K. K., Halisdemir, M., Bakülü, N., Hazar, R. G., Köse, S., \& Ünsal, Y. (2012). Okul öncesinde değerler ĕgitimi ve etkinlik örnekleri. Pegem yayıncılık.

Uygun, S. (2013). Değerler eğitimi program tasarılarının değerlendirilmesi (Antalya örneği). Mediterranean Journal of Humanities, 3(2), 263-277.

Uysal, E. (2008). Çağımızda değer kaymalarının doğurduğu sonuçlar ve etik kimliğin korunması. Uludăg Üniversitesi Illahiyat Fakültesi Dergisi, 17(1), 6779.

Uysal, H., Altun, S. A, ve Akgün, E. (2010). Okul öncesi öğretmenlerinin çocukların istenmeyen davranışlarıyla karşı karşıya kaldıklarında kullandığı stratejiler. Ilköğretim Online, 9(3), 971-979.

Üner, E. (2011). Okul öncesi eğitim programındaki 36-72 aylık çocuklara farklılıklara saygı ĕ̆itimi kazandırmanın öğretmen görüşleri doğrultusunda değerlendirilmesi (Yayımlanmış yüksek lisans tezi). Erciyes Üniversitesi, Eğitim Bilimleri Enstitüsü, Kayseri.

Yavuz, K. (2012). Çocukta dini duygu ve düşüncenin gelişmesi. Boğaziçi Yayınları.

Yazıc1, S. ve Aslan, M. (2011). Değer eğitiminde kahramanların rol modeli olarak kullanılması: Sosyal bilgiler ders kitapları ile öğretmen adaylarının kahraman seçimi arasında bir karşılaştırma. Eğitim bilimleri: teori ve uygulama. 11(4), 2184-2188.

Yıldırım, A. ve Simsek, H. (2012). Sosyal bilimlerde nitel araştırma yöntemleri. Seçkin. 
Extended Abstract

\title{
Pre-School Teachers Views on the National Values: Moral Education Through Influential Turkish Figures
}

\author{
Abdulhamit KARADEMIR, Corresponding Author, Assistant Professor. \\ Muş Alparslan University, Faculty of Education, Mus/Turkey. \\ a.karademir@alparslan.edu.tr \\ https://orcid.org/0000-0003-3062-8547 \\ İlknur ÇELIK, Teacher. \\ Republic of Turkey Ministry of National Education, Ankara/Turkey. \\ ilknur.6549@gmail.com \\ https://orcid.org/0000-0002-7481-511X
}

Article Type: Research Article

https://doi.org/10.34234/ded.762815

Received Date: 03.07 .2020

Accepted Date: 07.10 .2020

Published Date: 25.12 .2020

\section{Introduction}

Students are expected to acquire certain values at every level of schooling. However, preschoolers can also be provided with education programs that would help them develop and adopt mental, emotional, and moral skills within the framework of educational goals (Aydın, 2003). Starting in the early childhood years, people learn moral values throughout their lives (Balat, 2006: 7). Early childhood is a critical period of development, also known as preschool period, that last from birth to six years. This period witnesses a rapid mental, emotional, and moral development. 
It may be useful to address the moral principles and virtuous lifestyles of influential historical Turkish heroes, who represent the Turkish society, in order to achieve goals in preschool education programs and to teach values to children (Daysal-Ersoy, 2011). According to Egan (1988), children up to seven years of age can identify with historical figures and events on a simple level. During this period, children need the right examples to identify with. Not all models can contribute sufficiently to moral and cultural development, which in some cases may even negatively affect moral development (ko, 2014; Bushman and Huesmann, 2006). The personality traits and lives of heroes, and what they fought for and what they cared about can be made use of to teach students moral values and to help them distinguish between right and wrong. The actions and life stories of heroes reflect the moral standards and values of society (Yazıc1 \& Aslan, 2011). Influential historical figures who represent culture can help children learn moral norms and become altruistic individuals. Influential Turkish figures can meet the needs of children for heroes and help them develop cultural infrastructures and learn and put moral values into practice through lived experiences (Daysal-Ersoy, 2011; Ceran, 2015).

Influential Turkish figures addressed by this study symbolize national cultural values, and therefore, can help children become cognizant individuals who are willing to keep cultural images and values alive. As the great leader Mustafa Kemal Atatürk once stated, "A society that loses its national identity and values becomes morally corrupt and loses its significance in the eyes of other nations, and therefore, national morality and character must be fortified to raise a moral generation." We, therefore, believe that we should turn to our own self and moral values, despite general reservations about them. New generations should be provided with preschool moral education related to influential historical figures to enable them to learn their cultural heritage and adopt moral values and keep them alive (Demircioğlu and Tokdemir, 2008; Uysal, 2008). Influential Turkish figures are a valuable resource for children to learn about history, moral values, and national awareness and culture that are in line with the goals and target values of preschool education. However, there is limited research on preschool moral education through influential Turkish figures (Daysal-Ersoy, 2011; Ceran, 2015). We believe that this study will pave the way for further research on the issue and draw attention to the gap in the 2013-revised preschool curriculum of subjects concerning influential Turkish figures unique to our culture. We also believe that influential Turkish figures and related topics can help children build up moral, historical, and cultural foundations that they need in their future 
educational lives. It is of paramount importance to teach these unique virtues to children to turn them into new generations that represent our ancestors as they deserve to be.

\section{Method}

Phenomenology, which is a qualitative research design, was used in this study. The sample consisted of preschool teachers from kindergartens $(n=21)$ and nursery classrooms of primary schools $(n=2)$ in various districts in the city of Muş. The aim of this study was to determine preschool teachers' views of implications of values education associated with influential historical Turkish figures on preschool education. Data were collected using a semi-structured interview form. Face-to-face interviews were held at the place and time convenient to participants in the fall semester of 2019-2020 academic year.

Data were analyzed using inductive content analysis. Data were analyzed using second-cycle coding, which is used in qualitative research (Miles, Huberman \& Saldana, 2014). The QSR-NVivo 8 was used to develop codes and to interpret and explain the findings. To achieve reliability, the codes and themes were checked by a different expert who had experience in the field, and the agreed-upon codes and themes were finalized and then presented in Tables.

\section{Conclusion, Discussion, and Suggestions}

Participants perceive political leaders, Islamic philosophical figures, folk heroes, poets-writers, and scientists as influential Turkish figures. As for moral education through these people, they referred to concepts such as; virtue, having faith, perseverance, and success, being forethoughtful, and setting an example. This may be due to preschooler's tendency to be verbally and physically aggressive and exhibit negative behavior that violates the rights of their classmates and teachers (Uysal, Altun and Akgün, 2010). These results are consistent with the literature (Kolaç and Karadağ, 2012; Erkuş ve Yazar, 2013; Köse and Uzun, 2017; Ogelman and Sarıkaya, 2015; Kozikoğlu, 2018). The preschool education program addresses the concept of responsibility the most, which is followed by respect, cooperation, trust, love, tolerance, freedom, equality, friendship, and justice (Aral and Kadan, 2018).

Participants' responses (virtue and moral rules and behavior) are related to the concepts in the program. Besides, the preschool education program addresses 
the value of responsibility the most. However, only one participant makes mention of the value of responsibility, which is exceedingly low compared to what Ogelman and Sarıkaya (2015) reported. This may be due to variables, such as the current lifestyle, environmental conditions, problems faced in the classroom, and value judgments. This result shows that all values should be integrated into the curriculum in a more balanced and straightforward way than it currently is (Aral and Kadan, 2018). One of the goals of the National Education is "to raise individuals who adopt, protect, and develop the national, moral, human, spiritual, and cultural values of the Turkish nation" (Ministry of Education, 2013) Despite this, the preschool education program does not adequately address the national and cultural values (Aral and Kadan, 2018).

Education is a continuous process, and therefore, children should learn moral values from an early age on to avoid social and academic problems in the future and know how to cope with them when they need to (Balıkçı, 2016). Every effort put into moral values from early ages on can help children develop terminal behavior in the future. Therefore, moral values and concepts should be clearly explained in the program and activities. Özer and Çam Aktaş (2019) found that the primary and secondary education programs highlighted moral values clearly.

Research shows that preschoolers should be taught universal values (respect, love, peace, honesty, love of nature, responsibility, cooperation, peace, tolerance, etc.) (Tillman \& Hsu, 2000; Uyanık Balat et al., 2012). Participants stated that the drama method was the best method for teaching these values. The literature also shows that it is the right approach to teach preschoolers moral values. Some studies show that the creative drama method is another suitable method for teaching moral values to preschoolers because it allows them to bring different things from their own lives to it (Kaya, Günay \& Aydın, 2016; Kaya \& Antepli, 2018). Participants' second choice was educational play, which is also consistent with the literature. Educational play helps children not only develop various skills but also build social relationships that would contribute to the development of values. Peer socialization provides children with an opportunity to learn the values of respect, kindness, happiness, helpfulness, tolerance, responsibility, patience, belonging, sensitivity, courage, justice, and virtuous deeds without any coercion and pressure (Gündüz, Aktepe, Uzunoğlu and Gündüz, 2017). Participants' third choice was story reading, which is also consistent with the studies (Ural, 2013: 47-48) which assert that the story reading method 
contributes to moral education and helps children learn social and moral values. Activities involving techniques, such as story reading, role enactment, and gamification, can help children imagine influential Turkish figures vividly in their minds and learn moral values better (Balıkçı, 2016). The drama, play, and story-reading methods recommended by participants have also been reported by earlier studies (Bartan, 2018; Kozikoğlu, 2018; Köse \& Uzun, 2017).

Participants stated that the personality traits and moral values of influential Turkish figures should be set as role models for preschoolers. After all, children should be provided with the right role models to turn them into individuals "who adopt, protect, and develop the national, moral, human, spiritual, and cultural values of the Turkish nation," which is one of the goals of the National Education in Turkey. This study addressed preschool teachers' views of moral education through famous and influential Turkish figures. However, different studies have focused on distinct groups (Karakaş, 2015; Kolaç and Karadağ, 2012).

Participants also stated that schools and classrooms should have educational environments with rich material on Turkish history and centers for influential Turkish figures to facilitate the teaching of moral values to students. Üner (2011) argues that the lack of sufficient material and equipment in schools makes values education harder, a point which parallels our findings as well.

In conclusion, the interests and needs of the age group should be considered to specify the educational content of activities and applications for moral education. Regardless of the educational level, all activities and applications for moral education should focus not only on national but also on universal values, such as peace, tolerance, love, respect, and honesty. Educators should also use real life-based methods to help the target group internalize moral concepts and values. It takes time to establish social morality, and therefore, preschool moral education is of paramount importance to lay a solid foundation for social morality. Using influential Turkish figures to teach moral concepts and values can help achieve the goal of "teaching national and cultural values" set by the program. The personality traits and lives of great historical Turkish figures can facilitate moral education. Transformation of moral values throughout history and its causes and consequences, and great historical figures and events can be used to teach students moral values effectively. This is consistent with our results showing that preschool moral education offers permanent learning in children and that children internalize the personality traits and moral values of important Turkish figures (Daysal-Ersoy, 2011). Important Turkish figures can be used 
to teach students values and to help them develop their own personal values. From this perspective, using important Turkish figures for moral education can make it easier for educators to help students develop citizenship skills and adopt cultural values. These results show once again how important moral education is, especially in the preschool period, which referred to as "the magic years," tha should be associated with great historical figures, whom we are proud of. 